\title{
Chitin and Chitosan Preparation from Marine Sources. Structure, Properties and Applications
}

\section{Islem Younes ${ }^{1}$ and Marguerite Rinaudo ${ }^{2, *}$}

1 Laboratory of Enzyme Engineering and Microbiology, University of Sfax, National School of Engineering, PO Box 1173-3038, Sfax, Tunisia; E-Mail: islem.younes@gmail.com

2 Biomaterials Applications, 6 rue Lesdiguières, Grenoble 38000, France

* Author to whom correspondence should be addressed; E-Mail: marguerite.rinaudo@sfr.fr; Tel.: +336-1143-4806.

Academic Editors: David Harding and Hitoshi Sashiwa

Received: 26 December 2014 / Accepted: 16 February 2015 / Published: 2 March 2015

\begin{abstract}
This review describes the most common methods for recovery of chitin from marine organisms. In depth, both enzymatic and chemical treatments for the step of deproteinization are compared, as well as different conditions for demineralization. The conditions of chitosan preparation are also discussed, since they significantly impact the synthesis of chitosan with varying degree of acetylation (DA) and molecular weight (MW). In addition, the main characterization techniques applied for chitin and chitosan are recalled, pointing out the role of their solubility in relation with the chemical structure (mainly the acetyl group distribution along the backbone). Biological activities are also presented, such as: antibacterial, antifungal, antitumor and antioxidant. Interestingly, the relationship between chemical structure and biological activity is demonstrated for chitosan molecules with different DA and MW and homogeneous distribution of acetyl groups for the first time. In the end, several selected pharmaceutical and biomedical applications are presented, in which chitin and chitosan are recognized as new biomaterials taking advantage of their biocompatibility and biodegradability.
\end{abstract}

Keywords: chitin; chitosan; chemical and enzymatic deproteinization; demineralization; characterization; deacetylation; biological activities; biomedical applications 


\section{Introduction}

Chitin or poly $(\beta-(1 \rightarrow 4)-N$-acetyl-D-glucosamine) is a natural polysaccharide of major importance, first identified in 1884 (Figure 1). This biopolymer is synthesized by enormous number of living organisms [1] and it belongs to the most abundant natural polymers, after cellulose. In the native state, chitin occurs as ordered crystalline microfibrils which form structural components in the exoskeleton of arthropods or in the cell walls of fungi and yeast. So far, the main commercial sources of chitin are crab and shrimp shells. In industrial processing, chitin is extracted by acid treatment to dissolve the calcium carbonate followed by alkaline solution to dissolve proteins. In addition, a decolorization step is often added in order to remove pigments and obtain a colorless pure chitin. All those treatments must be adapted to chitin source, owing to differences in the ultrastructure of the initial material (the extraction and pre-treatments of chitin will be described later), to produce first a high quality chitin, and then chitosan (after partial deacetylation). Chitin is infusible and sparingly soluble during transformation into different conformations. The question of its solubility is a major problem in the development of both processing and use of chitin as well as its characterization.

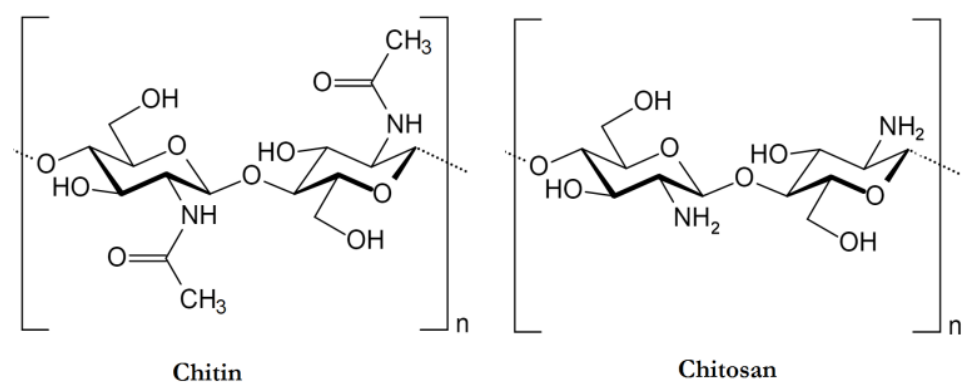

Figure 1. Chemical structure of chitin and chitosan

Chitin has more applications while transforming to chitosan (by partial deacetylation under alkaline conditions) [2-4]. Chitosan is a random copolymer with a molar fraction DA (degree of acetylation) of $\beta$ - $(1 \rightarrow 4)-N$-acetyl-D-glucosamine (Figure 1) and a fraction (1-DA) of $\beta$-(1 $\rightarrow 4)$-D-glucosamine (Figure 1). The degree of acetylation of chitosan is characterized by the molar fraction of $N$-acetylated units (DA) or as a percentage of acetylation (DA\%).

This review aims to present the state-of-the-art knowledge on the morphology of chitin and chitosan, the main techniques applied to chitin isolation and chitosan production. Then, the best methods for characterization in solution or solid state are also indicated. It is pointed out that for biomedical products, chitin and chitosan need to be highly purified, since residual proteins and pigments can cause side effects. Finally, the main biological properties will be analyzed in relation with the chemical structure (degree of acetylation and molecular weight of chitosan).

Concerning applications of chitin and chitosan, several examples used for drug release, wound dressing or biofilms are described. It is important to recall that chitin is a natural polymer as well as biocompatible and biodegradable in the body, thus widely used for biomedical and pharmaceutical applications. Additionally, good film forming properties are valuable for wound dressing, artificial skin or packaging. 


\section{Chitin Preparation and Characterization}

\subsection{Morphology of Chitin}

Depending on its source, chitin occurs as two allomorphs, namely the $\alpha$ and $\beta$ forms [5,6], which can be differentiated by infrared and solid-state NMR spectroscopies together with X-ray diffraction. In the solid state, chitin chains are assembled by the H-bonds network which controls the solubility, swelling and reactivity.

$\alpha$-Chitin isomorph is by far the most abundant; it occurs in fungal and yeast cell walls, in krill, lobster and crab tendons and in shrimp shells, as well as in insect cuticle. In addition to the native chitin, $\alpha$-chitin is systematically formed by: recrystallization from chitin solution $[7,8]$, by in vitro biosynthesis [9,10] or enzymatic polymerization [11] due to high thermodynamical stability of this isomorph.

The rarer $\beta$-chitin is found in association with proteins in squid pens $[5,12]$ and in the tubes synthesized by pogonophoran and vestimetiferan worms [13,14]. The crystallographic parameters of the two isomorphs allow us to conclude that there are two antiparallel molecules per unit cell in $\alpha$-chitin but only one in $\beta$-chitin in a parallel arrangement. In these two structures, the chains are organized in sheets and held by intra-sheet hydrogen bonds. In addition, in $\alpha$-chitin, inter-sheet hydrogen bonds prevent diffusion of small molecules into the crystalline phase. No inter-sheet hydrogen bonds are found in the crystal structure of $\beta$-chitin. This may explain its swelling in the presence of polar guest molecules (ranging from water to alcohol and amines) which penetrate the crystal lattice without disturbing the sheet organization and the crystallinity of the sample. The removal of the guest molecule allows us to revert to the original state of anhydrous $\beta$-chitin. The reactivity of $\beta$-chitin isomorph is larger than the $\alpha$-isomorph, which is important for enzymatic and chemical transformations of chitin [15]. To conclude, both $\alpha$ and $\beta$ forms are insoluble in all the common solvents. This insolubility is a major problem in the view of the development of processing and applications of chitin.

\subsection{Chitin Extraction}

The main sources of raw material for the production of chitin are cuticles of various crustaceans, principally crabs and shrimps. In crustaceans or more specifically shellfish, chitin is found as a constituent of a complex network with proteins onto which calcium carbonate deposits to form the rigid shell. The interaction between chitin and protein is very intimate and there is also a small fraction of protein involved in a polysaccharide-protein complex [16]. Thus, chitin isolation from shellfish requires the removal of the two major constituents of the shell, proteins by deproteinization and inorganic calcium carbonate by demineralization, together with small amounts of pigments and lipids that are generally removed during the two previous steps. In some cases, an additional step of decolorization is applied to remove residual pigments. Many methods have been proposed and used over the years to prepare pure chitin; however, no standard method has been adopted. Both deproteinization and demineralization could be carried out using chemical or enzymatic treatments. The order of two steps mentioned before may be reversed with some benefit, especially when 
enzymatic treatment is considered. Microbial fermentation is also employed; in that case deproteinization and demineralization steps are processed simultaneously.

Regardless to the selected treatment, the isolation of chitin begins with the selection of shells. For example, for lobsters and crabs, the selection has important bearing on the subsequent quality of the final isolated material. Ideally, shells of the same size and species are chosen. In the case of shrimps, the wall of shell is thinner, thus the chitin isolation is easier than from other types of shells. The selected shells are then cleaned, dried and ground into small shell pieces.

\subsubsection{Chemical Extraction}

\subsubsection{Chemical Deproteinization}

The deproteinization step is difficulty due to disruption of chemical bonds between chitin and proteins. This is performed heterogeneously using chemicals which also depolymerize the biopolymer. The complete removal of protein is especially important for biomedical applications, as a percentage of the human population is allergic to shellfish, the primary culprit being the protein component.

Chemical methods were the first approach used in deproteinization. A wide range of chemicals have been tested as deproteinization reagents including $\mathrm{NaOH}, \mathrm{Na}_{2} \mathrm{CO}_{3}, \mathrm{NaHCO}_{3}, \mathrm{KOH}, \mathrm{K}_{2} \mathrm{CO}_{3}, \mathrm{Ca}(\mathrm{OH})_{2}$, $\mathrm{Na}_{2} \mathrm{SO}_{3}, \mathrm{NaHSO}_{3}, \mathrm{CaHSO}_{3}, \mathrm{Na}_{3} \mathrm{PO}_{4}$ and $\mathrm{Na}_{2} \mathrm{~S}$. Reactions conditions vary considerably in each study. $\mathrm{NaOH}$ is the preferential reagent and it is applied at concentration ranging from 0.125 to $5.0 \mathrm{M}$, at varying temperature (up to $160{ }^{\circ} \mathrm{C}$ ) and treatment duration (from few minutes up to few days). In addition of deproteinization, the use of $\mathrm{NaOH}$ invariably results in partial deacetylation of chitin and hydrolysis of the biopolymer lowering its molecular weight.

\subsubsection{Chemical Demineralization}

Demineralization consists in the removal of minerals, primarily calcium carbonate. Demineralization is generally performed by acid treatment using $\mathrm{HCl}, \mathrm{HNO}_{3}, \mathrm{H}_{2} \mathrm{SO}_{4}, \mathrm{CH}_{3} \mathrm{COOH}$ and $\mathrm{HCOOH}[17,18]$. Among these acids, the preferential reagent is dilute hydrochloric acid. Demineralization is easily achieved because it involves the decomposition of calcium carbonate into the water-soluble calcium salts with the release of carbon dioxide as shown in the following equation:

$$
2 \mathrm{HCl}+\mathrm{CaCO}_{3} \longrightarrow \mathrm{CaCl}_{2}+\mathrm{H}_{2} \mathrm{O}+\mathrm{CO}_{2} \uparrow
$$

Most of the other minerals present in the shellfish cuticle react similarly and give soluble salts in presence of acid. Then, salts can be easily separated by filtration of the chitin solid phase followed by washing using deionized water.

Demineralization treatments are often empirical and vary with the mineralization degree of each shell, extraction time, temperature, particle size, acid concentration and solute/solvent ratio. The latter depends on the acid concentration, since it needs two molecules of $\mathrm{HCl}$ to convert one molecule of calcium carbonate into calcium chloride. In order to have a complete reaction, acid intake should be equal to the stoichiometric amount of minerals, or even greater. $[19,20]$. Since, it is difficult to remove all minerals (due to the heterogeneity of the solid), larger volume or more concentrated acid solution is used. Demineralization can be followed by acidimetric titration: the evolution of $\mathrm{pH}$ towards neutrality 
corresponds to acid consumption but the persistence of acidity in the medium indicates the end of the reaction [21].

Several demineralization treatments were previously used, involving various reaction conditions. Conventionally, demineralization is accomplished using dilute hydrochloric acid at different concentrations (up to $10 \% \mathrm{w} / \mathrm{v}$ ) at room temperature, during different incubations time (Table 1). Among such methods are those of Muzzarelli et al. [22], Hackman [23,24], Anderson et al. [25] (Table 1).

Exceptions to the above are seen in the methods of Horowitz et al. [26] and Synowiecki et al. [27] where demineralization was accomplished with $90 \%$ formic acid and $22 \% \mathrm{HCl}$, respectively, at room temperature. Most of the aforementioned methods include drastic treatments that may cause modifications, such as depolymerization and deacetylation of native chitin [28]. In order to overcome this problem, other methods have been developed using mild acids (to minimize degradation). For instance, Austin et al. [29] used ethylenediaminetetracetic acid (EDTA), Brine and Austin [30] applied acetic acid. Peniston and Johnson [31] studied a sulfurous acid process, etc. However, these treatments resulted in chitins with high residual ash content.

Demineralization using $\mathrm{HCl}$ usually can be achieved in 2 to $3 \mathrm{~h}$ under stirring [19]. However, reaction time varies with preparation methods from $15 \mathrm{~min}$ [18] to $48 \mathrm{~h}$ as seen in Table 1. Longer demineralization time, even to several days, results in a slight drop in the ash content but also causes polymer degradation [32,33].

Moreover, it was reported that the use of high temperature accelerates the demineralization reaction by promoting the penetration of the solvent into the chitin matrix. Thus, some demineralization reactions were carried out at higher temperature [34]. Furthermore, it was reported that the penetration of solvent into the chitin matrix strongly depends on the particles size. According to Marquis-Duval [35], the decisive factor in the demineralization is related to the contact area between the chitin matrix and the solvent. However, it was reported that high temperatures, longer incubations, high acid concentrations and granulometry affect the final physico-chemical properties of the resulting chitin.

In conclusion, although many experimental conditions can be found in the literature for the removal of minerals, effects on the molecular weight and acetylation degree cannot be avoided. Only Percot et al. [18] studied the extraction of chitin from shrimp shells using mild conditions allowing them to obtain chitin with a high DA. The demineralization was performed under the following conditions: at room temperature, in the presence of stoichiometric amount of $0.25 \mathrm{M} \mathrm{HCl}$ with regards to the calcium carbonate content, for $15 \mathrm{~min}$ incubation time. Deproteinization was later classically processed at $70{ }^{\circ} \mathrm{C}$ for $24 \mathrm{~h}$ using $1 \mathrm{M} \mathrm{NaOH}$. These conditions well preserve the chitin structure, with a high DA remaining above $95 \%$. Unfortunately, the amount of residual proteins and minerals were not determined and the influence on MW was not studied. 
Table 1. Comparison of conditions for chitin production according to literature.

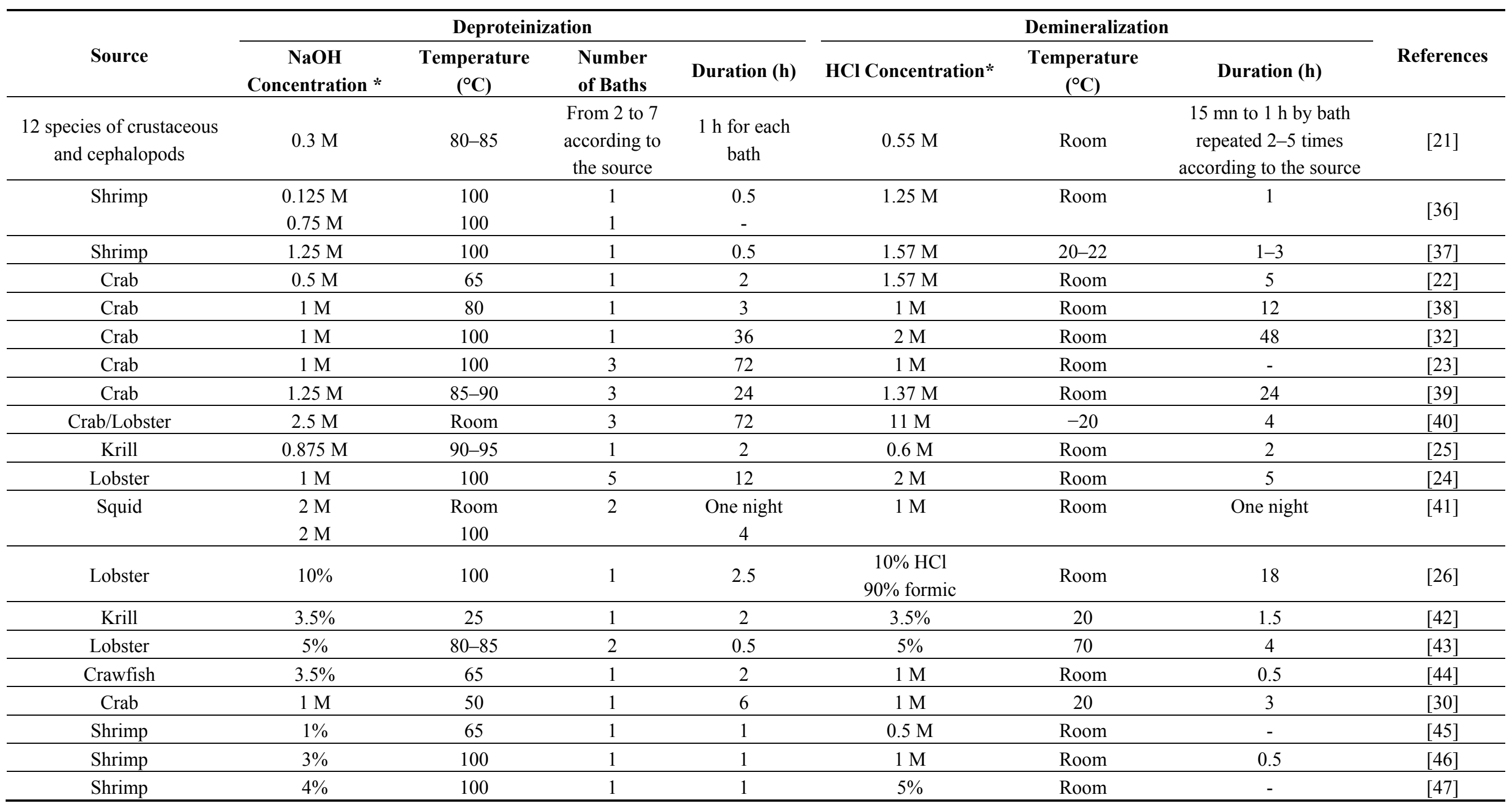

* Reactant concentrations are expressed in molarity or $\mathrm{w} / \mathrm{v} \%$. 


\subsubsection{Processes Preserving Chitin Structure}

To the best of our knowledge, there have been no studies which conduct a production of chitin with the highest DA and MW, free of minerals and proteins.

However, only the partial deacetylation may be controlled (using solid state ${ }^{13} \mathrm{C}-\mathrm{NMR}$ ). Furthermore, the chain degradation can be also evaluated by viscometry but after additional treatment, i.e., solubilization of residual chitin in specific solvent, or after conversion to a soluble product (chitosan). Nevertheless, in the last case, the deacetylation process is usually accompanied by polymer degradation. Thus, to estimate the influence of chitin extraction process, only DA is determined as indication of the degree of the chitin degradation. It may be assumed that the higher the DA is obtained for an extracted chitin, the less the polymer is degraded.

Optimized extraction method of pure chitin production with maximum preservation of its structure (MW, DA) allows us to get chitin corresponding to the native chitin in the cuticle structure. This approach was proposed by Tolaimate et al. [21] who used chemical treatments for both demineralization and deproteinization.

In the study of Tolaimate et al. [21], a new approach was proposed using successive baths of lower $\mathrm{HCl}(0.55 \mathrm{M})$ and $\mathrm{NaOH}(0.3 \mathrm{M})$ concentrations. The number of baths for each step was dependent on the tested animal species. This method has proved a good efficacy on the reduction of proteins and minerals as well as preservation of the native chitin form for 12 different species of crustaceous and cephalopods (Table 2). The DA of the prepared chitins, determined with ${ }^{13} \mathrm{C}-\mathrm{NMR}$, was varying between $96 \%$ and $100 \%$ for all the species. For example, for shrimp shells, extracted chitin was $100 \%$ acetylated. So far, such high degree of deacetylation has never been mentioned in the literature.

Table 2. Comparison of chitin production from different sources according to Tolaimate et al. [48].

\begin{tabular}{|c|c|c|c|c|}
\hline \multicolumn{2}{|c|}{ Source } & $\begin{array}{c}\begin{array}{c}\text { Number of } \\
\text { Deproteinization Baths }\end{array} \\
0.3 \mathrm{M} ; \mathrm{NaOH} 80^{\circ} \mathrm{C} ; 1 \mathrm{~h} \\
\end{array}$ & \multirow{2}{*}{$\begin{array}{c}\begin{array}{c}\text { Number of } \\
\text { Demineralization Baths }\end{array} \\
0.55 \mathrm{M} \mathrm{HCl} ; 25^{\circ} \mathrm{C} ; 2 \mathrm{~h} \\
\end{array}$} & DA \\
\hline & & 4 & & 100 \\
\hline Cirripedia & Anatife & 4 & 2 & 100 \\
\hline \multirow{3}{*}{$\begin{array}{l}\text { Reptantia } \\
\text { Brachyura }\end{array}$} & Red crab & 3 & 5 & 97 \\
\hline & Marbled crab & 3 & 3 & 99 \\
\hline & Spider crab & 3 & 3 & 96 \\
\hline \multirow{4}{*}{$\begin{array}{l}\text { Reptantia } \\
\text { Macrura }\end{array}$} & Lobster & 3 & 3 & - \\
\hline & Crayfish & 7 & 3 & 100 \\
\hline & slipper lobster & 3 & 2 & - \\
\hline & $\begin{array}{c}\text { Freshwater } \\
\text { crayfish }\end{array}$ & 3 & 2 & - \\
\hline \multirow{2}{*}{ Natantia } & Pink shrimp & 3 & 3 & 100 \\
\hline & Grey Shrimp & 2 & 2 & 100 \\
\hline Stomatopoda & Squilla & 3 & 3 & 100 \\
\hline Cephalopoda & Squid & 2 & 2 & 100 \\
\hline
\end{tabular}




\subsubsection{Biological Extraction of Chitin}

The extraction by chemical treatments has many drawbacks: (i) it harms the physico-chemical properties of chitin and leads to MW and DA decrease that negatively affects the intrinsic properties of the purified chitin; (ii) it affects wastewater effluent that contains some chemicals (iii) it increases the cost of chitin purification processes. Furthermore, the development of the green extraction techniques based on the concept of 'Green chemistry' is gaining greater attention, favoring the application of enzymes and microorganisms for chitin extraction. A comparative study was carried out by Khanafari et al. [49] for extraction of chitin from shrimp shells by chemical and biological methods. The results indicated that the biological method (using microorganisms) was better than the chemical one because it preserves the structure of chitin. Bustos and Healy [50] also demonstrated that chitin obtained by the deproteinization of shrimp shells with various proteolytic microorganisms has higher molecular weights in comparison with chemically prepared shellfish chitin. The biological extraction of chitin offers high reproducibility in shorter time, simpler manipulation, smaller solvent consumption and lower energy input. However, the biological method is still limited to laboratory scale studies.

Recently, two reviews have reported the most common biological methods used for chitin extraction [51,52], i.e., the use of proteolytic enzymes in order to digest the proteins or a fermentation process using microorganism which allows a digestion of both proteins and minerals.

The use of enzymes in the deproteinization step was first mentioned in the original Rigbv patent from 1934 but there has been a renewed interest in this approach since 1977. This work has led to the lactic acid bacterial fermentation process, studied more extensively later by Guerrero Legarreta et al. [53] and Cira et al. [54].

\subsubsection{Enzymatic Deproteinization}

Chitin extraction requires the use of proteases. Proteolytic enzymes are mainly derived from plant, microbial and animal sources. Many proteases such as alcalase, pepsin, papain, pancreatine, devolvase and trypsin remove proteins from crustacean shells and minimize the deacetylation and depolymerization during chitin isolation. This treatment may be performed either after, or before demineralization step of the solid material, which modifies the accessibility for the reactants.

Both purified and crude extracted proteases are used in the deproteinization step. However, commercially purified enzymes are expensive in contrast to crude proteases, which are not only cheaper but also more efficient due to the presence of coexisting proteases. Crude proteases are mainly derived from bacteria and fish viscera, bacterial proteases being the most common. Marine animals possess the same functional classes of enzymes, which are present in animal tissues and may be recovered in both active and stable forms for commercial use. In several of the major fish producing countries, the by-products represent about $50 \%$ of the seafood harvest [55]. These materials are largely underutilized and discarded as waste. Thus, application of these crude enzymes in the chitin extraction process could be interesting in decreasing the costs of this process as well as in preserving the environment.

It must be noted that the efficiency of enzymatic methods is inferior to chemical methods with approximately $5 \%-10 \%$ residual protein typically still associated with the isolated chitin. The final 
isolated chitin could be then treated with an additional $\mathrm{NaOH}$ treatment (under milder conditions and for a shorter time) to increase its purity and preserve the structure of chitin.

Many reports have demonstrated the application of bacterial proteases in deproteinization step. For example, Synowiecki and Al-Khateeb [56] applied enzymatic deproteinization on previously demineralized shrimp waste in order to produce chitin and a nutritionally valuable protein hydrolyzate. Alcalase 2.4 L (Novo Nordisk A/S), a serine endopeptidase obtained from Bacillus licheniformis, was used. This enzyme was selected due to its specificity for terminal hydrophobic amino acids, which generally leads to the production of non-bitter hydrolyzate and allows an easy control of the hydrolysis degree. The obtained hydrolyzate is a good source of essential amino acids in food applications. However, the effectiveness of deproteinization was limited by the presence of residual small peptides and amino acids attached to chitin molecules which persist after enzymatic hydrolysis. This method allows the isolation of chitin containing about $4 \%$ of protein impurities. Such purity is sufficient for many non-medical applications of chitin. Gilberg and Stenberg [57] also used alcalase 2.4 L for chitin, protein hydrolyzate and asthaxanthin recovery.

Manni et al. [58] compared the isolation of chitin from shrimp waste using Bacillus cereus SV1 crude alkaline proteases to the use of $1.25 \mathrm{M} \mathrm{NaOH}$. Shrimp shells were demineralized after deproteinization using dilute $\mathrm{HCl}$ treatment. The residual protein content was significantly higher in the chitin isolated with the enzymatic deproteinization than that obtained with alkali treatment $(10 \%$ compared to $6 \%$ ).

In another study, enzymatic deproteinization was optimized by Younes et al. [59] before demineralization. In this study many microbial proteases were compared on the basis of their efficiency in shrimp shells deproteinization. Six alkaline crude microbial proteases from Bacillus mojavensis A21, Bacillus subtilis A26, B. licheniformis NH1, B. licheniformis MP1, Vibrio metschnikovii J1 and Aspergillus clavatus ES1, were used. The highest deproteinization degree was obtained with B. mojavensis A21 proteases, being at about $76 \%$. Then, the effect of reaction conditions, i.e., mainly enzyme/substrate ratio, temperature and incubation time, on the deproteinization degree were optimized using response surface methodology to reach $88 \%$ deproteinization under the optimized conditions.

Recently many fish and marine invertebrate alkaline crude proteases have been applied for shrimp shell deproteinization. Mukhin and Novikov [60] studied the possibility of using crustacean waste both as a substrate and as a source of proteases. The shell proteins were degraded with crude proteases isolated from the hepatopancreas of crab. The objective was to optimize the protein hydrolyzate yield. However, even under the best conditions, i.e., temperature $=50{ }^{\circ} \mathrm{C}$, time $=12 \mathrm{~h}, \mathrm{pH}=8.4$, Enzyme/Substrate ratio of $6 \mathrm{~g} / \mathrm{kg}$, the degree of hydrolysis was never higher than $80 \%$.

Younes et al. [61] used alkaline proteases from the red scorpionfish Scorpaena scrofa for shrimp waste deproteinized up to $85 \%$. Activities of these crude alkaline proteases are probably related to the fish feeding mainly on crustaceans and mollusks inducing the nature and the specificity of its enzymes.

By contrast, when extraction is carried out by chemical process, the order of two steps (deproteinization and demineralization) does not have significant effect on the quality and the yield of the final chitin [62]. However, if enzymatic deproteinization is applied, the minerals presented in the cuticles may decrease the accessibility of the proteases and affect shrimp shells deproteinization efficiency. Thus, demineralization should be performed firstly. 


\subsubsection{Fermentation}

The cost of using enzymes can be decreased by performing deproteinization by fermentation process, which can be achieved by endogeneous microorganisms (called auto-fermentation) or by adding selected strains of microorganisms. This latter can be achieved by single-stage fermentation, two-stage fermentation, co-fermentation or successive fermentation.

Many microorganism species were proposed for crustacean shells fermentation as summarized by Arbia et al. [51]. Fermentation methods could be separated into two major categories: lactic acid fermentation and non-lactic acid fermentation.

\section{(a) Lactic Acid Fermentation}

Fermentation of crustacean shells can be performed by selected Lactobacillus sp. strain as inoculum which produces lactic acid and proteases. Lactic acid is obtained by conversion of glucose resulting in lower $\mathrm{pH}$ condition of silage suppressing the growth of spoilage microorganisms. Lactic acid reacts with the calcium carbonate, leading to the formation of a precipitate of calcium lactate separated from lighter shells which are recovered and rinsed with water. This process may be realized either on purified crustaceous shells, or on complete shrimp waste (including heads and viscera). Thus, deproteinization and simultaneous liquefaction of the proteins could occurred by action of proteases produced by added strains, or by gut bacteria present in the intestinal system of the treated shrimps, or by proteases present in the biowaste itself. The efficiency of lactic acid fermentation depends on many factors, mainly the species and quantity of inoculums, carbon source and its concentration, initial $\mathrm{pH}$ and $\mathrm{pH}$ evolution during fermentation, temperature and the duration of fermentation [63-65].

For example, Choorit et al. [66] used response surface methodology to optimize demineralization efficiency in fermented shrimp shells. Following variables were tested: sucrose concentration, initial $\mathrm{pH}$ value and soaking time, using Pediococcus sp. L1/2. Results showed an increase in demineralization degree (caused by higher sucrose concentration and soaking time) as well as an important effect of the initial $\mathrm{pH}$. Demineralization degree reached at about $83 \%$ at $\mathrm{pH} 7$, compared to $68 \%$ at $\mathrm{pH} 6$ (sucrose concentration $50 \mathrm{~g} / \mathrm{L}$ and soaking time $72 \mathrm{~h}$ ).

Otherwise, Rao et al. [64] studied the effect of different fermentation parameters (initial pH, initial glucose concentration and inoculation with different quantities of Lactobacillus) on deproteinization and demineralization degrees. Combined treatment with Lactobacillus and reduction of initial waste $\mathrm{pH}$ by addition of acetic acid produced lower deproteinization and higher demineralization degrees than treatment with Lactobacillus or acid individually. In addition, inoculation with Lactobacillus resulted in a high-quality protein liquor output, whereas autofermented waste (due to the presence of shrimp microflora) gave a strong stinky protein fraction. In the fermentation with lactic acid bacteria, the demineralization efficiency and the quality of the derived product are high, and the addition of commercial proteases may even increase deproteinization.

(b) Non Lactic-Acid Fermentation

In non-lactic acid fermentation, both bacteria and fungi were used for crustacean shells fermentation, for example: Bacillus sp. [67-69], Pseudomonas sp. [65,70,71] and Aspergillus sp.[72]. 
Ghorbel-Bellaaj et al. [69] evaluated six proteolytic Bacillus strains on the fermentation of shrimp waste: Bacillus pumilus A1, B. mojavensis A21, B. licheniformis RP1, B. cereus SV1, B. amyloliquefaciens An6 and B. subtilis A26. Results showed that all the Bacillus strains were able to deproteinize shrimp waste. The highest deproteinization degree was obtained using B. cereus SV1. These authors had also tested the role of additional amount of glucose on fermentation and they concluded that glucose had no significant effect on deproteinization degree and improved demineralization.

Sini et al. [68] had studied fermentation of shrimp shells in jaggery broth using B. subtilis. About $84 \%$ of the proteins and $72 \%$ minerals were removed; after this step the residue was treated with $0.8 \mathrm{~N}$ $\mathrm{HCl}$ and $0.6 \mathrm{~N} \mathrm{NaOH}$ to reduce residual proteins and minerals to satisfactory level at about $0.8 \%$ proteins and $0.8 \%$ minerals.

Many factors have been reported to influence the fermentation process and consequently deproteinization and demineralization efficiencies [65,66,73]. Ghorbel-Bellaaj et al. [70] used Plackett-Burman factorial design to screen the main factors influencing fermentation efficiency using $P$. aeruginosa A2. This method is thus quite useful in preliminary studies, in which the main objective is to select variables that can be fixed or eliminated in further optimization process. Only four variables were reported to be effective on deproteinization and demineralization degrees: shrimp shell concentration, glucose concentration, inocculum size and incubation time. Under these conditions: initial medium $\mathrm{pH}$, temperature, speed of agitation and volume of culture no effect on fermentation efficiency was observed. Then, from response surface methodology, under optimal conditions for fermented shrimp shells, maximum demineralization was $96 \%$, and deproteinization was $89 \%$ [70].

Proteolytic enzymes released from fungus $A$. niger were also tested for their deproteinization and demineralization efficiency of crustacean shells. Teng et al. [74] evaluated concurrent production of chitin from shrimp shells and fungi in a one-pot fermentation process where proteases from the fungi hydrolyze proteins into amino acids that in turn act as a nitrogen source for fungal growth. Results showed that residual proteins in the isolated shrimp chitin were below $5 \%$. The protein content in the fungal chitin was higher $(10 \%-15 \%)$. They concluded that fungi and shrimp shells supplementation with glucose in a single reactor led to release of protease by the fungi and enhance the deproteinization of shrimp shells. The hydrolyzed proteins in turn were utilized for fungal growth, leading to lower $\mathrm{pH}$ of the medium and further demineralization of the shrimp shells.

The various biological methods of chitin extraction by microorganisms are simple, more productive and environmentally friendly when compared to chemical processes. However, microbial fermentation has its drawbacks such as: longer processing time compared to chemical methods, poorer accessibility of proteases (caused by the presence of minerals which lead to high residual proteins). Nevertheless, deproteinization rate could be ameliorated depending on the end use requirements in particular for biomedical applications. This could be achieved by using simultaneous or successive processes such as two-step fermentations or co-fermentation of microorganisms. In order to obtain highly purified chitin, biotechnological process must be completed by further mild chemical treatment to remove the residual protein and minerals.

Recently, Gortani and Hours [52] concluded that a cost-effective, fast, and easily controllable industrial process for producing chitin of high MW and DA still requires further development and optimization of the extraction process, such as: minimization of chitin degradation and decrease the impurity levels to a satisfactory level highly desirable for specific applications. 


\subsection{Chitin Characterization and Solubility}

In the solid state, the chains are parallel in $\beta$-chitin and antiparallel in $\alpha$-chitin [75]. Their crystalline structures were reviewed in different papers using X-ray diffraction method [76-79], IR spectroscopy [80-86], and NMR [87-90]. Solid state ${ }^{13}$ C-NMR is a commonly used technique for differentiation of the two isomorphs [88], for determination of the deacetylation degree of chitin (DD) and for control of purification conditions. Figure 2 shows typical spectra for $\alpha$-chitin and chitosans with different acetylation degrees [90].

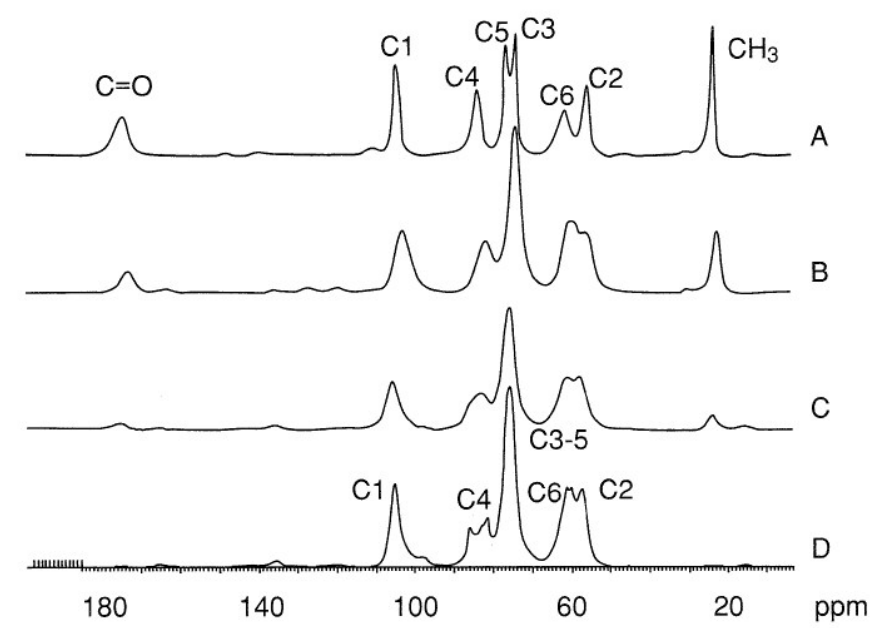

Figure 2. ${ }^{13} \mathrm{C}$ NMR spectra for (A) chitin and chitosans (B) obtained by homogeneous reacetylation $\mathrm{DA}=0.60 ;(\mathbf{C})$ commercial chitosan from Pronova $\mathrm{DA}=0.2$; (D) fully deacetylated chitin. Reproduced with permission from [90]. Copyright 2000 American Chemical Society.

Unfortunately, physical properties of chitin in solution cannot be analyzed correctly due to poor data caused mainly by difficulties in dissolution of this polymer. Dissolution is desired to estimate the molecular weight but also to process chitin (chitin cannot be processed in molten state). Presence of aggregates in solution precludes light scattering measurements and overestimates the molecular weights. Therefore, the most applicable technique here is viscometry where the Mark-Houwink parameters are known under defined thermodynamic conditions used (solvent, temperature). One of the mostly known system is based on complex formation between chitin and $\mathrm{LiCl}$ (at $5 \mathrm{wt} \%$ in the solvent DMAC) in dimethylacetamide solvent. Experimental values of parameters $K$ and $a$ relating intrinsic viscosity $[\eta]$ and molecular weight $M$ for chitin in this solvent are estimated from well-known Mark-Houwink equation according to:

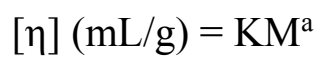

with $\mathrm{K}=7.6 \times 10^{-3}, \mathrm{a}=0.95$ at $30^{\circ} \mathrm{C}$ [91] and $\mathrm{K}=2.4 \times 10^{-1}$, a $=0.69$ at $25^{\circ} \mathrm{C}$ [92].

A review on chitin and chitosan including the question of their solubility was recently published in relation to fiber processing [93]. It has been demonstrated that chitin is able to be processed from solutions. Additionally, chitin, like other polysaccharides derived from cellulose, has good film-forming properties and good stability promoted by the establishment of a hydrogen bond network 
between extended chains. Chitin gives original properties to the new materials due to its biocompatibility, biodegradability and non-toxicity, with antimicrobial activity and low immunogenicity.

\section{Chitosan Preparation and Characterization}

\subsection{Chitosan Preparation}

The term chitosan usually refers to a family of polymers obtained after chitin deacetylation to varying degrees. In fact, the acetylation degree, which reflects the balance between the two types of residues (Figure 1), differentiates chitin from chitosan. When the DA (expressed as molar percentage) is lower than $50 \mathrm{~mol} \%$, the product is named chitosan and becomes soluble in acidic aqueous solutions [94]. During deacetylation, acetyl groups are removed but also depolymerization reaction occurs, indicated by changes in MW of chitosan.

Chitin can be converted to chitosan by enzymatic preparations [95-98] or chemical process [99,100]. Chemical methods are used extensively for commercial purpose of chitosan preparation because of their low cost and suitability to mass production [100].

\subsubsection{Chemical Deacetylation}

From a chemical point of view, either acids or alkalis can be used to deacetylate chitin. However, glycosidic bonds are very susceptible to acid; therefore, alkali deacetylation is used more frequently [100,101].

The $N$-deacetylation of chitin is either performed heterogeneously [102], or homogeneously [103]. Commonly, in the heterogeneous method, chitin is treated with a hot concentrated solution of $\mathrm{NaOH}$ during few hours, and chitosan is produced as an insoluble residue deacetylated up to $\sim 85 \%-99 \%$. According to the homogeneous method, alkali chitin is prepared after dispersion of chitin in concentrated $\mathrm{NaOH}\left(30 \mathrm{~g} \mathrm{NaOH} / 45 \mathrm{~g} \mathrm{H} \mathrm{H}_{2} \mathrm{O} / 3 \mathrm{~g}\right.$ Chitin) at $25{ }^{\circ} \mathrm{C}$ for $3 \mathrm{~h}$ or more, followed by dissolution in crushed ice around $0{ }^{\circ} \mathrm{C}$. This method results in a soluble chitosan with an average degree of acetylation of $48 \%-55 \%$ [99]. This process produces deacetylation with acetyl groups uniformly distributed along the chains, for example chitosan with DA $=10 \%$ after $580 \mathrm{~h}$ at $25^{\circ} \mathrm{C}$ [103].

Rinaudo and Domard [104] reported that the solubility of chitosan can be characterized not only by the fraction of 2-acetamido-2-deoxy-D-glucose units in the molecule but also by the $N$-acetyl group distribution. Aiba [105] showed that deacetylation reaction performed under heterogeneous conditions gives an irregular distribution of $N$-acetyl-D-glucosamine and D-glucosamine residues with some blockwise acetyl group distribution along polymeric chains. Thus, solubility and degree of aggregation of chitosan can vary in aqueous solutions leading to changes in their average characteristics. For instance, physico-chemical properties of such chitosans may differ from those of randomly acetylated chitosans obtained under homogeneous conditions.

Furthermore, variations in chitosan preparation may also result in changes of: DA, distribution of acetyl groups along the chains, MW and viscosity in solution [106,107].

In fact, many parameters in the deacetylation reaction can impact the characteristics of the final chitosan [108]. For instance, Rege and Block [109] had investigated the effect of temperature, processing time and mechanical shear on chitosan characteristics, and found that temperature and 
processing time have a significant effect on DA and MW. Tolaimate et al. [110] reported that chitosan DA is greatly affected by temperature and repetition of alkaline steps. Wu and Bough [45] studied the effects of time and $\mathrm{NaOH}$ concentration. Tsaih and Chen [111] also examined the effect of time reaction and temperature. All these studies were conducted using a classical one-variable-at-a-time experimentation. These reports indicate that MW and DA of chitosan are mainly affected by $\mathrm{NaOH}$ concentration, reaction time, temperature and repetition of alkaline steps. Additional factors such as reaction reagent, atmosphere, particle size, chitin and solvent ratio, and source of raw material were also tested in others studies [100,102,110,112].

Weska et al. [113] attempted to optimize chitin deacetylation by response surface methodology (controlling MW and/or DA) using temperature and reaction time variables. Hwang et al. [114] studied the effect of temperature, time and $\mathrm{NaOH}$ concentration on the deacetylation. Chang et al. [102] reported the influence of $\mathrm{NaOH}$ concentration, temperature and solution/chitin ratio and found that chitosan DA was decreasing with increase of temperature and $\mathrm{NaOH}$ concentration. Other parameters, such as: the use of alkali successive baths, atmospheric conditions and presence of different additives could influence deacetylation but were not considered previously in optimization studies.

Deacetylation was investigated using seven factors: the alkali reagent, its concentration, temperature, reaction time, the use of successive baths, atmospheric conditions and the use of sodium borohydride, a reducing agent [115]. For that purpose, a fractional factorial design was applied and a mathematical model was established to allow optimizing experimental conditions for chitosan of desired DA. Results clearly revealed a significant effect of temperature and the alkali reagent nature ( $\mathrm{NaOH}$ treatment is much more efficient than $\mathrm{KOH}$ ). It has been found that $\mathrm{DA}$ is significantly affected by the use of successive baths, reaction time and alkali concentration. By contrast, the atmospheric conditions (nitrogen or air) and the use of a reducing agent $\left(\mathrm{NaBH}_{4}\right)$ do not have significant effect on the DA of chitosan but MW of chitosan was higher under atmospheric nitrogen and addition of sodium borohydride which prevents polymer degradation. These results are in agreement with previous ones obtained with thiophenol and $\mathrm{NaBH}_{4}$ used as oxygen scavenger and reducing agent, respectively [116].

\subsubsection{Enzymatic Deacetylation}

Chemical deacetylation has also disadvantages: energy consumption; waste of concentrated alkaline solution, thus an increase of environmental pollution, broad and heterogeneous range of soluble and insoluble products.

In order to overcome these drawbacks in the chitosan preparation, an alternative enzymatic method exploiting chitin deacetylases has been explored. The use of chitin deacetylases for the conversion of chitin to chitosan, in contrast to the currently used chemical procedure, offers the possibility of a controlled, non-degradable process, resulting in the production of novel, well-defined chitosan [117]. This method is specially used to prepare chitosan oligomers.

Chitin deacetylase (EC 3.5.1.41) catalyzes the hydrolysis of $N$-acetamido bonds in chitin to produce chitosan. The presence of this enzyme activity has been reported in several fungi [118-123] and insect species [124]. The mostly well-studied enzymes are those extracted from the fungi Mucor rouxii [95,118,119], Absidia coerulea [120], Aspergillus nidulans [121] and two strains of Colletotrichum 
lindemuthianum [122,123]. All the enzymes are glycoproteins and are secreted either into the periplasmic region or into the culture medium. Furthermore, all enzymes exhibit a remarkable thermal stability at their optimal temperature $\left(50{ }^{\circ} \mathrm{C}\right)$, and exhibit a very strong specificity for $\beta$ - $(1,4)$-linked $\mathrm{N}$-acetyl-D-glucosamine polymers. However, the enzymes vary significantly in their MW and carbohydrate content and display a wide range of $\mathrm{pH}$ optima. It is interesting to notice that chitin deacetylases, produced by $C$. lindemuthianum and A. nidulans, are not inhibited by acetate (a product of the deacetylation) which make them suitable for potential biotechnological applications [121-123].

The efficiency of chitin deacetylase, isolated from the fungus $M$. rouxii, on the chitosan preparation was tested using chitin as a substrate (both in its crystalline and amorphous morphology) [125]. Deacetylation degrees remain very low $(<10 \%)$ indicating that the enzyme is not really effective on insoluble chitins. Similar results were also obtained using chitin deacetylases isolated from other sources $[120,122,123]$. Thus, pretreatment of chitin substrates before enzyme addition seems to be necessary in order to improve the accessibility of the acetyl groups to the enzyme and therefore to enhance the deacetylation yield. For that purpose, experiments have been performed in homogeneous conditions using chitin deacetylase from $M$. rouxii with partially deacetylated water-soluble chitosans [126]. In selected conditions, the enzyme is able to deacetylate chitosan up to $97 \%$ (deacetylation from an initial chitosan with $\mathrm{DA}=0.32$ and a number-average degree of polymerization of 30) [126].

These findings suggest that the development of a controllable process using the enzymatic deacetylation on chitinous substrates is an attractive alternative process that can result in the preparation of novel chitosan polymers and more interestingly oligomers.

\subsection{Chitosan Characterization and Solubility}

Chitosan obtained from partial deacetylation of chitin becomes soluble in aqueous acidic medium when the average degree of acetylation DA is lower than 0.5. In fact, this limit depends on the distribution of acetyl groups along the chains. At this stage, it is possible to obtain a complete characterization of the polymer but it may differ from the starting material, specially its molecular weight is reduced during deacetylation in strong alkaline medium, as mentioned previously.

The physical properties of chitosan in solution depend strongly on DA and on the acetyl group distribution along the chains. Block-wise distribution of acetyl groups, caused by heterogeneous deacetylation performed on solid state chitin, causes chain association even in dilute solutions and formation of aggregates as well as difficulties in molecular weight determination [127,128]. In addition, fully deacetylated chitosan may be reacetylated in homogeneous phase [129] in order to get samples soluble in acidic conditions up to DA 0.6 in relation with a random distribution of the acetyl groups. Under these conditions, the existence of free $-\mathrm{NH}_{2}$ groups, available on $\mathrm{C}-2$ position of D-glucosamine units along the chains, allows to perform specific reactions in homogeneous conditions [130-136].

The first step in chitosan characterization is the determination of their molecular weights (after dissolution), then DA and eventually the distribution of acetyl group along the chain (by NMR). Additionally, different solvents based on acetic acid have been proposed, for instance: $0.3 \mathrm{M}$ acetic acid added with sodium acetate (up to 0.1 or $0.2 \mathrm{M}$ ) in aqueous solution. The presence of an external 
salt is needed to screen the long-range electrostatic repulsions between the charged chains. Chitosan is also soluble in acetic acid or hydrochloric acid at $\mathrm{pH}$ lower than 6 (its intrinsic $\mathrm{pK}$ being around 6.5) [1].

The determination of average DA for chitosan may be performed by different techniques: infrared spectroscopy [86], elementary analysis, and potentiometric titration, but ${ }^{1} \mathrm{H}$ liquid state [89] and solid state ${ }^{13} \mathrm{C}$-NMR $[90,137,138]$ are preferred. Infrared spectroscopy has to be used carefully because the result interpretation is related to the difficulty in adopting a convenient base line. This problem was also discussed previously for samples with different DAs [86]. At present, ${ }^{1} \mathrm{H}$ NMR seems to be the most convenient technique to get the correct DA for soluble samples. An example is given in Figure 3. Additionally, ${ }^{13} \mathrm{C}$ NMR is also convenient for DA determination in the case of pure chitin up to fully deacetylated chitosan with a good agreement between measurements in solid state and liquid phase (Figure 2) [90].

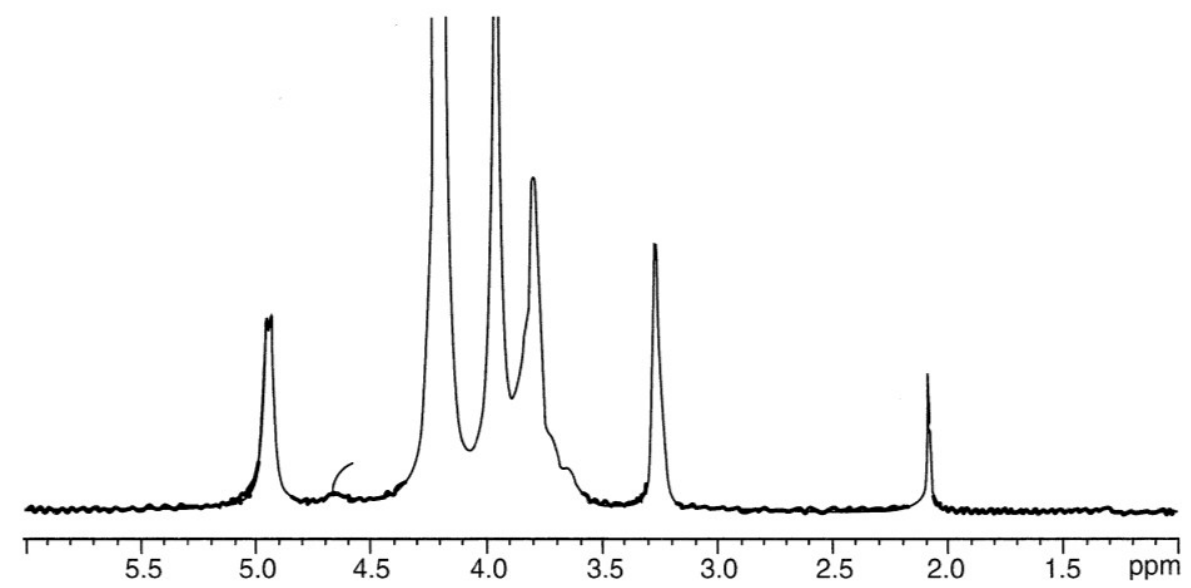

Figure 3. ${ }^{1} \mathrm{H}-\mathrm{NMR}$ spectrum of chitosan with $\mathrm{DA} \sim 0.06$ in $\mathrm{D}_{2} \mathrm{O}$ at $\mathrm{pH} \sim 4, \mathrm{~T}=85{ }^{\circ} \mathrm{C}$ and polymer concentration $5 \mathrm{~g} / \mathrm{L}$. Signals at $4.9 \mathrm{ppm}$ is for $\mathrm{H}-1$ of D-glucosamine unit, at $4.7 \mathrm{ppm}$ is for $\mathrm{H}-1$ of $N$-acetyl-D-glucosamine, at $3.2 \mathrm{ppm}$ is for $\mathrm{H}-2$ and at $2.1 \mathrm{ppm}$ is for $-\mathrm{CH}_{3}$ of the acetyl group allowing to get DA.

It is important to recall that high field ${ }^{13} \mathrm{C}-\mathrm{NMR}$ spectroscopy is important to establish the distribution of acetyl groups along the chitosan chains $[139,140]$.

Furthermore, the molecular weight distribution and the average molecular weight as well as the intrinsic viscosity also play a significant role. However, chitosan solution must be free of aggregates, thus the solvent for chitosan must be chosen carefully. The viscometric-average molecular weight has been usually calculated from intrinsic viscosity (lower impact of small fractions of aggregates) using the Mark-Houwink relationship [1]. In order to determine $K$ and $a$ parameters, an absolute MW has to be calculated using light scattering technique; nevertheless, the obtained value is usually overestimated due to high sensitivity to aggregate formation $[127,128]$. These artifacts may be omitted for instance by the use of $0.3 \mathrm{M}$ acetic acid/ $0.2 \mathrm{M}$ sodium acetate $(\mathrm{pH}=4.5)$ solvent which does not form aggregates in this mixture [141]. Under these conditions, the absolute $M$ values were obtained from steric exclusion chromatography (SEC) equipped with viscometer and light scattering detector on line allowing to determine the Mark-Houwink parameters without fractionation and also to obtain the relation between the radius of gyration and the molecular weight [142]. The $K(\mathrm{~mL} / \mathrm{g})$ and $a$ parameters at $25^{\circ} \mathrm{C}$ are $7.9 \times 10^{-2}$ and 0.796 respectively. 
The relatively high values obtained for the parameter $a$ are in agreement with the semi-rigid character of this polysaccharide which controls their dimensions, hydrodynamic volume and viscometric contribution. The stiffness is related to the persistence length $\left(L_{t}\right)$ of the chain: chitosan in acid medium behaves like a polyelectrolyte, so the actual total persistence length $L_{t}$ at a given ionic concentration is equal to the intrinsic contribution $L_{p}$ and the electrostatic contribution $L_{e}$, calculated following the Odijk treatment [143]. The conformational analysis of chitin with different degrees of deacetylation confirms that chitin and chitosan are semi-rigid polymers characterized by a persistence length which depends moderately on the degree of acetylation of the molecule. From this analysis, chitosan, free of acetyl groups, has an intrinsic persistence length $L_{p}$ of $9 \mathrm{~nm}$ in salt excess [144]. $L_{p}$ increases when DA increases up to $12.5 \mathrm{~nm}$ for $\mathrm{DA}=0.6$, remaining constant up to pure chitin at $25^{\circ} \mathrm{C}$. These predictions are in agreement with the experimental values obtained by SEC [142].

\subsection{Processing and Main Properties of Chitosan-Based Materials}

Solutions of chitosan prepared in acidic medium are processed to the needed conformation (casted for a film, spun for fibers, freeze dried for sponges, etc.), immersed in an alkaline solution (in which they precipitate), washed and dried. The processing of chitosan is easier than that of chitin but the stability of the materials is lower due to the larger hydrophilic character and especially the $\mathrm{pH}$ sensitivity. For better stability, chitosan may be crosslinked using reagents such as epichlorohydrin, diisocyanate, 1,4-butanediol diglycidyl ether, or glutaraldehyde [145-147]. Many chitosan hydrogels were obtained by treatment with multivalent anions as oxalic acid [148,149] or citric acid [150-152] or tripolyphosphate [153]. Blends and composites are sometimes produced taking advantage of the polycationic properties of chitosan in acidic conditions.

In fact, chitosan being a polyelectrolyte is able to form interesting electrostatic complexes (hydrogels) with oppositely charged macromolecules. The properties of these complex materials depend on the polymer concentration, temperature, $\mathrm{pH}$ and ionic concentration. Electrostatic polyelectrolyte complexes (PEC) are mentioned in the literature involving chitosan complexed with synthetic or natural polymers [4]. Electrostatic interactions between chitosan and lipidic vesicles are also important in the biological and pharmaceutical fields due to bioadhesive and permeabilizer roles of chitosan [154-156]. Coating of liposomes with chitosan also increases their biocompatibility, and stabilizes the composite membrane against $\mathrm{pH}$ as well as ionic concentration [155].

Nowadays, these electrostatic interactions are applied for preparation of layer-by-layer polyelectrolyte capsules or films based on charged biocompatible polysaccharides or chitosan/synthetic polyelectrolytes [157-159]. Core-shell phospholipid nanoparticles were stabilized via layer-by-layer self-assembly of anionic alginate and cationic chitosan and were proposed for protein release [157].

Chitosan and alginate electrostatic complexes have been mostly used so far for biological applications [160-162]. Complexes formed between DNA or RNA and chitosan (oligomers or polymers) are actually under further investigation in many laboratories; the charge density and DA of chitosan are essential for the complex stability [163-167]. 


\section{Relation between Chemical Structure and Biological Activities}

Because chitosan and derivatives possess many beneficially properties such as biocompatibility, biodegradability, safety and also interesting biological activities, much attention has been paid to their applications especially in biomedical, food, biotechnology and pharmaceutical fields [168,169]. Among their attractive biological activities, antimicrobial, antioxidant and antitumor activities will be discussed in detail below. These properties are specially recognized in the field of food preservation and packaging to avoid the use of chemical preservatives and to produce edible antimicrobial films due to the good film forming properties of chitosan. Chitosan, as a polymeric ingredient with a good antimicrobial and antioxidant properties, does not migrate easily out of the protecting film and has better barrier properties. This was previously demonstrated in many studies, such as those of Friedman et al. [170], Kardas et al. [171] and Alishahi and Aider [172].

Friedman et al. [170] studied the antimicrobial activities of chitosan in solution, powders and edible films and coating against foodborne pathogens, spoilage bacteria, and pathogenic viruses and fungi in several food categories. These include fruit juices, eggs and dairy, cereal, meat and seafood products. They suggest that low-molecular-weight chitosans at a $\mathrm{pH}$ below 6.0 presents optimal conditions for achieving desirable antimicrobial and antioxidative-preservative effects in liquid and solid foods.

The use of chitosan and derivatives in the food industry was also described in the review of Kardas et al. [171]. They demonstrated that these biopolymers offer a wide range of unique applications including preservation of foods from microbial deterioration and formation of biodegradable films.

Alishahi and Aider [172] reported that chitosan films in packaging application tend to exhibit resistance to fat diffusion and selective gas permeability. But, inconvenience comes from their low resistance to water and water vapor transmission. This behavior is due to the strongly hydrophilic character mainly of chitosan, a property that leads to high interaction with water molecules [173]. For this reason, polymer blending or the use of biocomposites and multilayer systems are potential approaches to prepare chitosan-based bioactive coatings.

\subsection{Antimicrobial Activity}

Chitosan was shown to have several advantages over other disinfectants, as it possesses a higher antimicrobial activity, a broader spectrum of activity, a higher kill rate, and lower toxicity towards mammalian cells [174,175]. Many studies have demonstrated that chitosan have an important antimicrobial activity. However, the actual mechanism of inhibition is not yet fully understood. The most feasible hypothesis is a change in cell permeability due to interactions between the positively charged polysaccharide (chitosan at $\mathrm{pH}$ lower than 6.5) and the negatively charged membrane. The mechanism underlying the inhibition of bacterial growth should be that the positively charged polymer combines with anionic components such as $\mathrm{N}$-acetylmuramic acid, sialic acid and neuraminic acid, on the cell surface.

Firstly, concerning the antibacterial activity of chitosan, possible actions of chitosan and its derivatives have been proposed. Chitosan (especially low-MW particles) could penetrate cell wall of bacteria, combine with DNA and inhibit synthesis of mRNA and DNA transcription [176]. High MW chitosan could interact with cell surface and consequently alter cell permeability [177], or form an 
impermeable layer around the cell, thus blocking the transport of essential solutes into the cell $[178,179]$. Chung et al. [180] confirmed that antibacterial mechanism includes hydrophilicity and the negative charge of cell surface and the adsorption of chitosan onto the bacterial cell. They show that cell wall hydrophilicity and negative charge of the cell surface were higher in gram-negative bacteria compared to gram-positive and that, in addition, the distribution of negative charges on their cell surfaces was quite different from that of gram-positive. Then, the more negatively charged cell surfaces interact more with positively charged chitosan, in acidic conditions. Their results showed a high value of correlation coefficient between adsorbed chitosan and inhibition efficiency. Moreover, many other studies showed that chitosans are more effective for gram-negative bacteria than gram-positive bacteria [181-183].

It was also indicated that adsorbed amounts of chitosan were related to environmental $\mathrm{pH}$ values $(\mathrm{pH}<6.5)$ and degree of acetylation of chitosan [183-185]. Chitosan is more absorbed by bacterial cells at lower $\mathrm{pH}$ in relation with the increase of the chitosan positive ionic charge in relation with the fraction of deacetylated groups $(1-D A)$. From literature, it is clearly shown that there is a direct relationship between the antibacterial activity of chitosan and its characteristics especially DA. Effect of DA on chitosan antimicrobial activity has been clearly demonstrated in our previous study [186]. In these data, it is clearly shown that the lower DA, the lower MW and the lower $\mathrm{pH}$ give the larger efficiency.

In addition, influence of the MW was introduced by Zheng et al. [187]. They differentiated the effect of chitosan on Staphylococcus aureus (gram-positive) and on Escherichia coli (gram-negative) and demonstrated that, for gram-positive $S$. aureus, the antimicrobial activity increases with increase of the molecular weight of chitosan. On the opposite, for gram-negative E. coli, they indicate that the antibacterial activity increased with decrease in molecular weight. These authors suggested the two following mechanisms for the antimicrobial activity: in the case of $S$. aureus, the chitosan on the surface of the cell forms a polymeric membrane, which inhibits nutrients from entering into the cell and, for E. coli, chitosan with a lower molecular weight entered the cell through pervasion.

Effect of MW was also discussed by Benhabiles et al. [188] preparing oligomers of chitin and chitosan. Their antimicrobial activities against four gram-positive and seven gram-negative bacteria were compared to initial chitosan and chitin. They conclude that chito-oligomers would have advantages as new antimicrobial agents due to their higher activity and larger water solubility than the native polysaccharides.

Concerning the antifungal activity, it has been reported that chitosan can reduce the infection of Fusarium oxysporum f. sp. apii in celery and inhibits the spread of Sphaerotheca pannosa var. rosae, Peronospora sparsa and Botrytis cinerea on roses [189-191]. Treating tomato plants with chitosan solution reduced mycelial growth, sporangial production, release of zoospores and germination of cysts of Phytophthora infestans which resulted in significant disease protection [192]. In addition, chitosan seed treatment could reduce Colletotrichum sp. infection and improve performance of chilli seedling [193]. Concerning the mechanism, it is suggested that chitosan forms a permeable film at interface [194] and has two functions: direct interference of fungal growth and activation of several defense processes. These defense mechanisms include accumulation of chitinases, synthesis of proteinase inhibitors, lignification and induction of callous synthesis [195]. 
In fact, dependence of activities on chitosan characteristics was reported to depend on the particular fungal species. For example, it was shown that fungal growth decreased with increasing MW for F. oxysporum and with decreasing DA for Alternaria solani, but no MW or DA dependences were observed with $A$. niger [186].

\subsection{Antioxidant Activity}

Oxidative stress belongs to the main causes of many diseases, mainly cancer and cardiovascular problems, which significantly increase the worldwide mortality [196-202]. Dietary antioxidants, which inactivate reactive oxygen species and provide protection from oxidative damage [196-202], are considered as important preventive strategic molecules.

Once the lipid oxidation occurs in food products, off-flavors and undesirable chemical compounds are formed and this may be dangerous for health. Therefore, in order to minimize this risk, some antioxidants (like synthetic antioxidants butylated hydroxyanisole (BHA), butylated hydroxytoluene (BHT), t-butylhydroquinone (TBHQ) and propyl gallate) are added to delay the deterioration, caused by lipid oxidation. However, these antioxidants create potential health hazards, and their use has been restricted in some countries. Therefore, there has been a growing interest in natural antioxidants rather than in synthetic ones.

In recent years, much more attention has been paid to study the antioxidant activity of chitosan and its derivatives [203]. It was reported that chitosan and its derivatives act as antioxidants by scavenging oxygen radicals such as hydroxyl, superoxide, alkyl as well as highly stable DPPH radicals tested in vitro [204]. Sun and collaborators [205] reported that chitosan and their derivatives act as hydrogen donors to prevent the oxidative sequence.

Furthermore, it was observed that the radical scavenging properties of chitosans depend on their DA and MW. Park et al. [204] demonstrated that low-MW chitosans are more active than those with higher MW. Chitosan samples with low MW (1 3 kDa) revealed higher potential to scavenge different radicals. Other examination showed that low-MW chitosans can exhibit more than $80 \%$ of superoxide radical scavenging activity at $0.5 \mathrm{mg} / \mathrm{mL}$ concentration [206]. The influence of chitosan MW (30, 90, and $120 \mathrm{kDa})$ on the antioxidant activity in Salmon skin was also studied [207]. The results of this study showed that all chitosans present antioxidant activities, which reduce Salmon lipid oxidation, the $30-\mathrm{kDa}$ chitosan sample having the higher antioxidant activity. In addition, highly deacetylated (90\%) chitin are more preferable for scavenging DPPH, hydroxyl, superoxide and carbon-centered radicals [208]. Even though the precise mechanism of radical scavenging activity is not clear, it is attributed to amino and hydroxyl groups (attached to C-2, C-3 and C-6 positions of the pyranose ring) reacting with unstable free radicals, which facilitate formation of stable macromolecule radicals.

\subsection{Antitumor Activity}

Chitosan and its derivatives possess also antitumor activities investigated by both in vitro and in vivo method [209]. Some in vivo studies reported that chitosan inhibits the growth of tumor cells by exerting immunoenhancing effects. They concluded that the observed antitumor activity was not due to a direct killing of tumor cells, but by an increase of lymphokines production resulting in proliferation 
of cytolytic T-lymphocytes [210]. Chen et al. [211] demonstrated that intratumoral administration of a chitosan gel in animals reduces metastatic breast cancer progression. Chitosan also stimulates macrophages maturing into cytotoxic macrophages and suppresses tumor growth in mice [212]. It has been suggested that elevated secretion of IL-1 and IL-2 causes the anti-tumor effect through maturation and infiltration of cytolytic T-lymphocytes [213].

Other studies demonstrated that chitosan also exhibits a direct effect on tumor cells; it inhibits tumor cell proliferation by inducing apoptosis [214]. For instance, Hasegawa et al. [215] showed that chitosan may cause apoptotic death of bladder tumor cells via caspase-3 activation. Further studies revealed that chitosan nanoparticles could also induce necrotic death, which had been tested on liver cancer cells via neutralization of cell surface charge, observed as a decrease in mitochondrial membrane potential and induction of lipid peroxidation [216]. Moreover, chitosan may inhibit Ehrlich ascites tumor growth by reduction of glycolysis causing a decrease in glucose uptake and ATP level in the tumor cells [217]. This study also found that chitosan administered orally at a dose of $1 \mathrm{mg} \mathrm{kg}^{-1}$ in mice reduces tumor growth by $\sim 62 \%$, without any toxicity to the liver. Thus, chitosan per se possesses potential activity against cancer, even when it is administered orally. A similar study, using a chemically-induced tumor model, showed that addition of chitosan to the diet enables to suppress aberrant crypt tumor lesions in the colon of mice [218]. Interestingly, such protection with chitosan additive in feed lasts only up to 6 weeks. This investigation highlighted that chitosan is responsible for an increase in expression of p21/Cip and p27/Kip and consequently a decrease of expression of proliferating cell nuclear antigen in a human gastric cancer cell line. Nevertheless, further studies are required in order to better understand all mechanisms involved in chitosan-based tumor stasis.

Chitosan activity depends not only on the chitosan structural characteristics, such as DA and MW, but also on tumor species. Jeon and Kim [219] studied the antitumor activity of chitosan oligosaccharides with different molecular weights. They found that chitosan oligosaccharides with MW ranging from 1.5 to $5.5 \mathrm{kDa}$ may effectively inhibit the growth of Sarcoma 180 solid (S180) or Uterine cervix carcinoma No. 14 (U14) tumor in BALB/c mice. Studies on mice examining chitosan samples with different MW revealed significant antimetastatic effects of chitosan against Lewis lung carcinoma. It was shown that the activity increases with decreasing the molecular sizes suggesting an immunostimulating effect which activates peritoneal macrophages and stimulates non-specific host resistance. It was also shown that chitosan samples with higher MW exhibits lower antitumor activity [220]. However, other authors found that decrease of MW of chitosan from 213 to $10 \mathrm{kDa}$ does not affect its in vitro cytotoxicity on human lung carcinoma cell line A549 [221]. Additionally, chitosan samples with different MW ranging from 42 to $135 \mathrm{kDa}$ were also evaluated in terms of their cytotoxicity on human bladder cancer RT112 and RT112cp cells and no effect of MW was observed [222]. The same study attempted to examine also the effect of chitosan DA (homogeneous chitosans with DA ranging from $2 \%$ to $61 \%$ ) on cytotoxicity. The results from this experiment indicated that all chitosan samples were active on bladder carcinoma cells, with better activity for samples with higher DA.

It has been shown that chitosan reveals anticancer activity, thus it may be used for encapsulation of anticancer agents. However, before its incorporation into new drugs, pre-tests are required. 


\section{Pharmaceutical and Biomedical Applications of Chitin and Chitosan}

The main properties of chitin and chitosan, applied for specific applications, have been already described such as: biocompatibility, renewable origin, non-toxicity [223], non-allergenicity and biodegradability in the body [224]. In addition, due to their attractive biological activities (antifungal, antibacterial, antitumor, immunoadjuvant, antithrombogenic, anticholesteremic agent) and bioadhesivity (especially of chitosan and its derivatives [225]), they are widely used as absorption promoters and hydrating agents, as well as for film production and wound healing [1-4,226]. Chitin and more easily chitosan may be processed, depending on the intended application, into different conformations such as fibers, powders, films, sponges, beads, solutions, gels and capsules [171]. Consequently, chitosan may be used in oral, nasal as well as ocular routes, for drug delivery in both implantable and injectable forms. Chitin and chitosan in fiber or film state, are mainly applied for tissue engineering and wound care dressing [227-229]. Additionally, transmucosal absorption promoter effect of chitosan is especially important for nasal and oral delivery of polar drugs to administrate peptides and proteins and for vaccine delivery [230,231]. Cationic chitosan may affect transport of ions through an interaction with the cell surface (inducing perturbation of membrane phospholipids bilayers). Chitin is also used as excipient and drug carrier in film, gel or powder form for applications involving mucoadhesivity [52]. Actually, the main promising developments are aimed to pharmaceutical and biomedical domains [232-245]. Several selected applications for chitin and chitosan will be described below and summarized in Table 3 .

Applications of chitin are less developed compared to those of chitosan due to its large insolubility and difficulties in processing. Therefore, chitin is very often combined with chitosan which gives in fact similar applications.

Chitin accelerates wound-healing in spray, gel and gauze [246-249]. It is used as support of medicaments or to control drug release [238] taking into account the biodegradability, low toxicity, physiological inertness, antibacterial properties, hydrophilic character, gel forming properties, affinity for proteins and mucoadhesivity [250].

Great attention had been paid to a composite material made of hydroxyapatite-chitin-chitosan which may be used as bone filling material for guided tissue regeneration (treatment of periodontal bony defects). This composite forms a self-hardening paste [251-261]. Chitin was also used for enzymes and whole cells immobilization [262] as well as for tissue engineering [263,264].

Chitosan (the only pseudo-natural polycationic substance) and its electrostatic complexes formed with synthetic or natural polymers (as alginate) are used as antithrombogenic materials for: controlled release, drugs encapsulation, enzymes and cells immobilization and also as gene carriers. Advantage of chitosan-based materials is related to their biodegradability, antibacterial activity, hydrophilic property, as well as presence of polar groups which are able to form secondary interaction with other polymers (-OH and $-\mathrm{NH}_{2}$ groups involved in hydrogen bonds and the $\mathrm{N}$-acetyl groups in hydrophobic interactions). 
Table 3. Main applications of chitin and chitosan in pharmaceutical and biomedical domains.

\begin{tabular}{|c|c|}
\hline Forms & Applications \\
\hline Beads & Drug delivery [266] \\
\hline Microspheres [265] & Enzyme immobilization \\
\hline & Gene delivery vehicle [267] \\
\hline Nanoparticles & Encapsulation of sensitive drugs [172] \\
\hline Coatings & $\begin{array}{l}\text { Surface modification } \\
\text { Textile finishes }\end{array}$ \\
\hline \multirow[t]{2}{*}{ Fibers } & Medical textiles \\
\hline & Suture \\
\hline \multirow[t]{2}{*}{ Nanofibers [268] } & Guided bone regeneration \\
\hline & Scaffold for nerve tissue regeneration \\
\hline \multirow[t]{2}{*}{ Nonwonen bioactive fibers [269] } & Wound healing \\
\hline & Wound care \\
\hline \multirow{3}{*}{ Films } & Dialysis membrane \\
\hline & Antitumoral [270] \\
\hline & Semi-permeable film for wound dressing [271] \\
\hline \multirow{3}{*}{ Powder } & Adsorbent for pharmaceutical and medical devices \\
\hline & Surgical glove powder \\
\hline & Enzyme immobilization \\
\hline \multirow{5}{*}{ Sponge [272] } & Mucosomal hemostatic dressing \\
\hline & Wound dressing \\
\hline & Drug delivery [272] \\
\hline & Enzyme entrapment \\
\hline & Artificial skin [271] \\
\hline \multirow{2}{*}{ Shaped objects } & Orthopedics \\
\hline & Contact lenses \\
\hline \multirow{7}{*}{ Solutions } & Cosmetics \\
\hline & Bacteriostatic agent \\
\hline & Hemostatic agent \\
\hline & Anticoagulants \\
\hline & Antitumor agent \\
\hline & Gene delivery [267] \\
\hline & Spermicide [245] \\
\hline \multirow{4}{*}{ Gels } & Delivery vehicle \\
\hline & Implants, coating \\
\hline & Tissue engineering \\
\hline & Wound dressing for wet treatment [271] \\
\hline \multirow{3}{*}{ Tablets } & Compressed diluent \\
\hline & Disintegrating agent \\
\hline & Excipient [273] \\
\hline Capsules & Delivery vehicle \\
\hline
\end{tabular}

Materials for wound dressing and tissue engineering are important but still under development [274-282]. New adhesives were also proposed [283,284]. The Az-chitosan derivative is non-toxic, cytocompatible and mechanically suitable for peripheral surgeries [285]. Chitosan films, like 
many other polysaccharide-based films, exhibit resistance to fat diffusion and selective gas permeability but they are relatively poor in terms of resistance to the transmission of water and water vapor. This behavior is observed due to their hydrophilic character leading to high interaction with water molecules [173]. In order to overcome this problem, polymer blending or biocomposites and multilayer systems are used for preparation of chitosan-based bioactive and stable coatings.

Mucoadhesivity of chitosan and its cationic derivatives is recognized and proved to enhance the adsorption of drugs especially at neutral $\mathrm{pH}$. $N$-trimethyl chitosan chloride interacts with the negatively charged cell membranes [286]. $N$-lauryl-carboxymethylchitosan being an amphiphilic polymer forms micelles solubilizing taxol which becomes more efficient. This type of chitosan derivative is safe in terms of membrane toxicity and it could be useful as carrier for hydrophobic cancer drugs [287,288]. Chitosan or its derivatives were used for gene transfection. It was shown for $N$-alkylated chitosan that transfection efficiency increases upon elongation of the alkyl side chains up to eight carbons in the side chain [289]. Quaternized chitosan was also used for the same purpose [290]. Porous chitosan (and derivatives) microspheres were prepared in order to deliver antigens in a controlled way [291]. This type of particles was loaded with Newcastle disease virus vaccine and tested in vitro and in vivo [291,292].

An interesting application of the chitosan- calcium phosphate cement was found. Chitosan or chitosan glycerophosphate was mixed with calcium phosphate and citric acid and an attractive injectable self-hardening system for bone repair or filling indications was formed [253-255].

At the end, several examples of applications for drug delivery are mentioned [265,293-296]. Chitosan may be processed more easily than chitin to different forms: in sponge, capsule or nanoparticle depending on the tested system and the goal of its administration.

\section{Conclusions}

In this review, the characteristics of chitin and chitosan are described. This was followed by a discussion on the solubilization required to process the polysaccharides to obtain new materials. Their fiber and film-forming abilities are recognized on the basis of the H-bonds network formation in the solid state which may be useful for new potential applications.

However, the most important applications come from their hydrophilic character and antimicrobial properties, especially desired for production of new biomaterials.

Chitosan in comparison with chitin is soluble in acidic media, which is applied for improvement of processing methods. In fact, chitosan may be easily processed as fiber, film, sponge, bead, gel or solution. Additionally, its cationic charge provides the possibility to form electrostatic complexes and/or multilayer structures. The presence of free $-\mathrm{NH}_{2}$ groups along chitin and chitosan chains allows to perform specific modifications (performed on the C-2 position of the D-glucosamine unit) under pretty mild conditions (even in aqueous conditions with chitosan). Furthermore, chitin and chitosan can be blended with synthetic or natural polymers (proteins, DNA, alginate, hyaluronan, etc.).

\section{Acknowledgments}

The authors would like to thank Anna Wolnik for her valuable contribution to ameliorate the English language of this manuscript. 


\section{Author Contributions}

This work was performed in strong cooperation between the two co-authors.

\section{Conflicts of Interest}

The authors declare no conflict of interest.

\section{References}

1. Rinaudo, M. Chitin and chitosan: Properties and applications. Prog. Polym. Sci. 2006, 31, 603-632.

2. Rinaudo, M. Main properties and current applications of some polysaccharides as biomaterials, Polym. Int. 2008, 57, 397-430.

3. Rinaudo, M. Physical properties of chitosan and derivatives in sol and gel states. In Chitosan-Based Systems for Biopharmaceuticals: Delivery, Targeting and Polymer Therapeutics; Sarmento, B., das Neves, J., Eds.; John Wiley \& Sons: Chichester, UK, 2012; pp. 23-44.

4. Rinaudo, M. Materials based on chitin and chitosan. In Bio-Based Plastics: Materials and Applications; Kabasci, S., Ed.; John Wiley \& Sons: Chichester, UK, 2014; pp. 63-80.

5. Rudall, K.M.; Kenchington, W. The chitin system. Biol. Rev. 1973, 40, 597-636.

6. Blackwell, J. Chitin. In Biopolymers; Walton, A.G., Blackwell, J., Eds.; Academic Press: New York, NY, USA, 1973; pp. 474-489.

7. Persson, J.E.; Domard, A.; Chanzy, H. Single crystals of a-chitin. Int. J. Biol. Macromol. 1990, 13, 221-224.

8. Helbert, W.; Sugiyama, J. High-resolution electron microscopy on cellulose II and $\alpha$-chitin single crystals. Cellulose 1998, 5, 113-122.

9. Ruiz-Herrera, J.; Sing, V.O.; van der Woude, W.J.; Bartnicki-Garcia, S. Microfibril assembly by granules of chitin synthetase. Proc. Natl. Acad. Sci. USA 1975, 72, 2706-2710.

10. Bartnicki-Garcia, S.; Persson, J.; Chanzy, H. An electron microscope and electron diffraction study of the effect of calcofluor and congo red on the biosynthesis of chitin in vitro. Arch. Biochem. Biophys. 1994, 310, 6-15.

11. Sakamoto, J.; Sugiyama, J.; Kimura, S.; Imai, T.; Itoh, T.; Watanabe, T.; Kobayashi, S. Artificial chitin spherulites composed of single crystalline ribbons of $\alpha$-chitin via enzymatic polymerization. Macromolecules 2000, 33, 4155-4160.

12. Rudall, K.M. Chitin and its association with other molecules. J. Polym. Sci. Part C 1969, 28, 83-102.

13. Blackwell, J.; Parker, K.D.; Rudall, K.M. Chitin in pogonophore tubes. J. Mar. Biol. Assoc. UK 1965, 45, 659-661.

14. Gaill, F.; Persson, J.; Sugiyama, P.; Vuong, R.; Chanzy, H. The chitin system in the tubes of deep sea hydrothermal vent worms. J. Struct. Biol. 1992, 109, 116-128.

15. Kurita, K.; Tomita, K.; Ishi, S.; Nishimura, S-I.; Shimoda, K. $\beta$-chitin as a convenient starting material for acetolysis for efficient preparation of $\mathrm{N}$-acetylchitooligosaccharides. J. Polym. Sci. A Polym. Chem. 1993, 31, 2393-2395. 
16. Horst, M.N.; Walker, A.N.; Klar, E. The pathway of crustacean chitin synthesis. In The Crustacean Integument: Morphology and Biochemistry; Horst, M.N., Freeman, J.A., Eds.; CRC: Boca Raton, FL, USA, 1993; pp. 113-149.

17. No, H.K.; Hur, E.Y. Control of foam formation by antifoam during demineralization of crustacean shell in preparation of chitin. J. Agric. Food. Chem. 1998, 46, 3844-3846.

18. Percot, A.; Viton, C.; Domard, A. Characterization of shrimp shell deproteinization. Biomacromolecules 2003, 4, 1380-1385.

19. Johnson, E.L.; Peniston, Q.P. Utilization of shellfish waste for chitin and chitosan production. In Chemistry \& Biochemistry of Marine Food Products; Martin, R.E., Flick, G.J., Hebard, C.E., Ward, D.R., Eds.; AVI Publishing Co.: Westport, CT, USA, 1982; Chapter 19, p. 415.

20. Shahidi, F.; Synowiecki, J. Isolation and characterization of nutrients and value-added products from snow crab (Chifroeceles opilio) and shrimp (Panda-111sb orealis) processing discards. J. Agric. Food Chem. 1991, 39, 1527-1532.

21. Tolaimate, A.; Desbrieres, J.; Rhazi, M.; Alagui, A. Contribution to the preparation of chitins and chitosans with controlled physico-chemical properties. Polymer 2003, 44, 7939-7952.

22. Muzzarelli, R.A.A.; Tanfani, F.; Emanuelli, M.; Gentile, S. The chelation of cupric ions by chitosan membranes [Callinectes sapidus, blue crab shell]. J. Appl. Biochem. 1980, 2, 380-389.

23. Hackman, R.H. Studies on chitin. I. Enzymatic degradation of chitin and chitin esters. Aust. J. Biol. Sci. 1954, 7, 168-178.

24. Hakman, R.H.; Goldberg, M. Light-scattering and infrared-spectrophotometric studies of chitin and chitin derivatives. Carbohydr. Res. 1974, 38, 35-45.

25. Anderson, G.G.; de Pablo, N.; Romo, C. Antartic krill (Euphausia superba) as a source of chitin and chitosan. In Proceedings of First International Conference on Chitin and Chitosan; Muzzarelli, R.A.A., Priser, E.R., Eds.; Mit Sea Grant Program: Cambridge, MA, USA, 1978; pp. 54-63.

26. Horowitz, S.T.; Roseman, S.; Blumental, H.J. Preparation of glucosamine oligosaccharides. 1. Separation. J. Am. Chem. Soc. 1957, 79, 5046-5049.

27. Synowiecki, J.; Sikorski, Z.E.; Naczk, M. Immobilization of invertase on krill chitin. Biotechnol. Bioeng. 1981, 23, 231-233.

28. Foster, A.B.; Webber, J.M. Chitin. Adv. Carbohydr. Chem. 1960, 15, 371-393.

29. Austin, P.R.; Brine, C.J.; Castle, J.E.; Zikakis, J.P. Chitin: New facets of research. Science 1981, 212, 749-753.

30. Brine, C.J.; Austin, P.R. Chitin variability with species and method of preparation. Comp. Biochem. Physiol. 1981, 69B, 283-286.

31. Peniston, Q.P.; Lohnson, E.L. Process for Demineralization of Crustacea Shells. U.S. Patent 4,066,735, 3 January 1978.

32. Shimahara, K.; Ohkouchi, K.; Ikeda, M. In Chitin Chemistry; Roberts, G.A.F., Ed.; Macmillan Press: London, UK, 1992; p. 56.

33. Okafor, N. Isolation of chitin from the shell of the cuttlefish, Sepia oficirralis L. Biochim. Biophys. Acta 1965, 101, 193-200.

34. Truong, T.; Hausler, R.; Monette, F.; Niquette, P. Fishery industrial waste valorization for the transformation of chitosan by hydrothermo-chemical method. Rev. Sci. Eau 2007, 20, 253-262. 
35. Marquis-Duval, F.O. Isolation et valorisation des constituants de la carapace de la crevette nordique. Ph.D. Dissertation, Laval University, Quebec, Canada, 2008.

36. Madhavan, P.; Nair, K.G.R. Utilisation of prawn waste-isolation of chitin and its conversion to chitosan. Fish. Technol. 1974, 11, 50-53.

37. Moorjani, M.N.; Achutha, V.; Khasim, D.I. Parameters affecting the viscosity of chitosan from prawn waste. J. Food Sci. Technol. 1975, 12, 187-189.

38. Mima, S.; Miya, M.; Iwamoto, R.; Yoshikawa, S. Highly deacetylated chitosan and its properties. J. Appl. Polym. Sci. 1983, 28, 1909-1917.

39. Broussignac, P. Un haut polymère naturel peu connu dans l'industrie, Le chitosane. Chim. Ind. Genie Chim. 1968, 99, 1241-1247.

40. BeMiller, J.N.; Whistler, R.L. Alkaline degradation of amino sugars. J. Org. Chem. 1963, 27, 1161-1164.

41. Kurita, K.; Tomita, K.; Tada, T.; Ishii, S.; Nishimura, S.I.; Shimoda, K. Squid chitin as a potential alternative chitin source: Deacetylation behavior and characteristic properties. J. Polym. Sci. Pol. Chem. 1993, 31, 485-491.

42. Brzeski, M.M. Concept of chitin chitosan isolation from Antartic Krill (Euphausia superba) shells on a technical scale. In Proceedings of the Second International Conference on Chitin and Chitosan; Hirano, S., Tokura, S., Eds.; The Japan Society of Chitin and Chitosan: Sapporo, Japan, 1982; pp. 15-29.

43. Blumberg, R.; Southall, C.L.; van Rensburg, N.J.; Volckman, O.B. South African fish products. XXXII-The rock lobster: A study of chitin production from processing wastes. J. Sci. Food Agric. 1951, 2, 571-576.

44. No, H.K.; Meyers, S.P.; Lee, K.S. Isolation and characterization of chitin from crawfish shell waste. J. Agric. Food Chem. 1989, 37, 575-579.

45. Wu, A.C.M.; Bough, W.A. A study of variables in the chitosan manufacturing process in relation to molecular-weight distribution, chemical characteristics and waste-treatment effectiveness. In Proceedings of the 1st International Conference on Chitin/Chitosan, Boston, USA, 11-13 April 1977; Muzzarelli, R.A.A., Pariser, E.R., Eds.; MIT Sea Grant Program, Massachusetts Institute of Technology: Cambridge, MA, USA, 1978; pp. 88-102.

46. Bough, W.A.; Salter, W.L.; Wu, A.C.M.; Perkins, B.E. Influence of manufacturing variables on the characteristics and effectiveness of chitosan products 1 . Chemical composition, viscosity, and molecular-weight distribution of chitosan products. Biotechnol. Bioeng. 1978, 20, 1931-1943.

47. Sluyanarayana Rao, S.V.; Yashodha, K.P.; Mahendrakar, N.S. Puttarajappa. Deacetylation of chitin at low temperature by a novel alkali impregnation technique. Indian J. Technol. 1987, 25, 194-196.

48. Tolaimate, A. Exploration des gisements chitineux de la faune marine marocaine. Procédé d'extraction de chitines fortement acétylées. Préparation de chitosanes à caractéristiques contrôlées. Ph.D. Dissertation, Cadi Ayyad University, Marrakech, Maroc, 2000.

49. Khanafari, A.; Marandi, R.; Sanatei, S. Recovery of chitin and chitosan from shrimp waste by chemical and microbial methods. Iran. J. Environ. Health Sci. Eng. 2008, 5, 1-24. 
50. Bustos, R.O.; Healy, M.G. Microbial deproteinization of waste prawn shell. In Proceedings of the Second International Symposium on Environmental Biotechnology; Biotechnology' 94: Brighton, UK, 1994; pp. 15-25.

51. Arbia, W.; Arbia, L.; Adour, L.; Amrane, A. Chitin extraction from crustacean shells using biological methods-A review. Food Technol. Biotech. 2013, 51, 12-25.

52. Gortari, M.C.; Hours, R.A. Biotechnological processes for chitin recovery out of crustacean waste: A mini-review. Electron. J. Biotechnol. 2013, 16, 14-14.

53. Guerrero Legarreta, I.; Zakaria, Z.; Hall, G.M. Lactic fermentation of prawn waste: Comparison of commercial and isolated starter cultures. In Advances in Chitin Science; Domard, A., Jeuniaux, C., Muzzarelli, R., Roberts, G., Eds.; Jacques Andre publishers: Lyon, France, 1996; Volume I, pp. 399-406.

54. Cira, L.A.; Huerta, S.; Guerrero, I.; Rosas, R.; Shirai, K. Scaling up of lactic acid fermentation of prawn wastes in packed-bed column reactor for chitin recovery. In Advances in Chitin Science; Peter, M.G., Domard, A., Muzzarelli, R.A.A., Eds.; Potsdam University: Postdam, Germany, 2000; Volume IV, pp. 2-27.

55. Rao, M.B.; Tanksale, A.M.; Ghatge, M.S.; Deshpande, V.V. Molecular and biotechnological aspects of microbial proteases. Microbiol. Mol. Biol. Rev. 1998, 62, 597-635.

56. Synowiecki, J.; Al-Khateeb, N.A.A.Q. The recovery of protein hydrolysate during enzymatic isolation of chitin from shrimp Crangon crangon processing discards. Food Chem. 2000, 68, $147-152$.

57. Gildberg, A.; Stenberg, E. A new process for advanced utilisation of shrimp waste. Process Biochem. 2001, 36, 809-812.

58. Manni, L.; Ghorbel-Bellaaj, O.; Jellouli, K.; Younes, I.; Nasri, M. Extraction and characterization of chitin, chitosan, and protein hydrolysates prepared from shrimp waste by treatment with crude protease from Bacillus cereus SV1. Appl. Biochem. Biotechnol. 2010, 162, 345-357.

59. Younes, I.; Ghorbel-Bellaaj, O.; Nasri, R.; Chaabouni, M.; Rinaudo, M.; Nasri, M. Chitin and chitosan preparation from shrimp shells using optimized enzymatic deproteinization. Process Biochem. 2012, 47, 2032-2039.

60. Mukhin, V.A.; Novikov, V.Y. Enzymatic hydrolysis of proteins from crustaceans of the Barents Sea. Appl. Biochem. Micro+ 2001, 37, 538-542.

61. Younes, I.; Nasri, R.; Bkahiria, I.; Jellouli, K.; Nasri, M. New proteases extracted from red scorpionfish (Scorpaena scrofa) viscera: Characterization and application as a detergent additive and for shrimp waste deproteinization. Food Bioprod. Process. 2014, doi:10.1016/ j.fbp.2014.06.003.

62. Kaur, S.; Dhillon, G.S. Recent trends in biological extraction of chitin from marine shell wastes: A review. Crit. Rev. Biotechnol. 2015, 35, 44-61.

63. Prameela, K.; Murali Mohan, C.; Smitha, P.V.; Hemablatha, K.P.J. Bioremediation of shrimp biowaste by using natural probiotic for chitin and carotenoid production an alternative method to hazardous chemical method. Int. J. Appl. Biol. Pharm. Technol. 2010, 1, 903-910.

64. Rao, M.S.; Muñoz, J.; Stevens, W.F. Critical factors in chitin production by fermentation of shrimp biowaste. Appl. Microbiol. Biotechnol. 2000, 54, 808-813. 
65. Oh, K.T.; Kim, Y.J.; Nguyen, V.N.; Jung, W.J.; Park, R.D. Demineralization of crab shell waste by Pseudomonas aeruginosa F722. Process Biochem. 2007, 42, 1069-1074.

66. Choorit, W.; Patthanamanee, W.; Manurakchinakorn, S. Use of response surface method for the determination of demineralization efficiency in fermented shrimp shells. Bioresour. Technol. 2008, 99, 6168-6173.

67. Yang, J.K.; Shih, I.L.; Tzeng, Y.M.; Wang, S.L. Production and purification of protease from a Bacillus subtilis that can deproteinize crustacean wastes. Enzyme Microb. Technol. 2000, 26, 406-413.

68. Sini, T.K.; Santhosh, S.; Mathew, P.T. Study on the production of chitin and chitosan from shrimp shell by using Bacillus subtilis fermentation. Carbohydr. Res. 2007, 342, 2423-2429.

69. Ghorbel-Bellaaj, O.; Younes, I.; Maalej, H.; Hajji, S.; Nasri, M. Chitin extraction from shrimp shell waste using Bacillus bacteria. Int. J. Biol. Macromol. 2012, 51, 1196-1201.

70. Ghorbel-Bellaaj, O.; Jellouli, K.; Younes, I.; Manni, L.; Ouled Salem, M.; Nasri, M. A solvent-stable metalloprotease produced by Pseudomonas aeruginosa A2 grown on shrimp shell waste and its application in chitin extraction. Appl. Biochem. Biotechnol. 2011, 164, 410-425.

71. Wang, S.L.; Chio, S.H. Deproteination of shrimp and crab shell with the protease of Pseudomonas aeruginosa K-1Enzy. Microb. Technol. 1998, 22, 629-633.

72. Mahmoud, N.S.; Ghaly, A.E.; Arab, F. Unconventional approach for demineralization of deproteinized crustacean shells for chitin production. Am. J. Biochem. Biotechnol. 2007, 3, 1-9.

73. Jung, W.J.; Kuk, J.H.; Kim, K.Y.; Park, R.D. Demineralization of red crab shell waste by lactic acid fermentation. Appl. Microbiol. Biotechnol. 2005, 67, 851-854.

74. Teng, W.L.; Khor, E.; Tan, T.K.; Lim, L.Y.; Tan, S.C. Concurrent production of chitin from shrimp shells and fungi. Carbohydr. Res. 2001, 332, 305-316.

75. Atkins, E.D.T. Conformation in polysaccharides and complex carbohydrates. J. Biosci. 1985, 8, 375-387.

76. Gonell, H.W. Roëtgenographische studien an chitin. Z. Physiol. Chem. 1926, 152, 18-30.

77. Clark, G.L.; Smith, A.F. X-ray studies of chitin, chitosan, and derivatives. J. Phys. Chem. 1936, 40, 863-879.

78. Gardner, K.H.; Blackwell, J. Refinement of the structure of $\beta$-chitin. Biopolymers 1975, 14, 1581-1595.

79. Minke, R.; Blackwell, J. The structure of $\alpha$-chitin. J. Mol. Biol. 1978, 120, 167-181.

80. Darmon, S.E.; Rudall, K.M. Infra-red and X-ray studies of chitin. Disc. Faraday. Soc. 1950, 9, 251-260.

81. Pearson, F.G.; Marchessault, R.H.; Liang, C.Y. Infrared spectra of crystalline polysaccharides. V. Chitin. J. Polym. Sci. 1960, 13, 101-116.

82. Falk, M.; Smith, D.G.; McLachlan, J.; McInnes, A.G. Studies on chitin (b-(1-4)-linked 2-acetamido-2-deoxy-D-glucan) fibers of the diatom Thalassiosira fluviatilis Hustedt. II.Proton magnetic resonance, infrared and X-ray studies. Can. J. Chem. 1966, 44, 2269-2281.

83. Galat, A.; Koput, J.; Popowicz, J. Analyses of infrared amide bands of chitin. Acta Biochim. Pol. 1979, 26, 303-308. 
84. Iwamoto, R.; Miya, M.; Mima, S. Vibrational polarization spectra of $\alpha$-type chitin. In Chitin and Chitosan, Proceedings of the Second International Conference on Chitin and Chitosan, Sapporo, Japan, 12-14 July 1982; Hirano, S., Tokura, S., Eds.; The Japanese Society of Chitin and Chitosan:Tottori, Japan, 1982; pp. 82-86.

85. Focher, B.; Naggi, A.; Torri, G.; Cosani, A.; Terbojevich, M. Structural differences between chitin polymorphs and their precipitates from solutions-evidence from CP-MAS 13CNMR, FT-IR and FT-Raman spectroscopy. Carbohydr. Polym. 1992, 17, 97-102.

86. Brugnerotto, J.; Lizardi, J.; Goycoolea, F.M.; Arguelles-Monal, W.; Desbrieres, J.; Rinaudo, M. An infrared investigation in relation with chitin and chitosan characterization. Polymer 2001, 42, 3569-3580.

87. Saito, H.; Tabeta, R.; Hirano, S. Conformation of chitin and $N$-acyl chitosans in solid state as revealed by $13 \mathrm{C}$ cross polarization/magic angle spinning (CP/MAS) NMR spectroscopy. Chem. Lett. 1981, 10, 1479-1482.

88. Tanner, S.F.; Chanzy, H.; Vincendon, M.; Roux, J.C.; Gaill, F. High resolution solid-state carbon-13 nuclear magnetic resonance study of chitin. Macromolecules 1990, 23, 3576-3583.

89. Kono, H. Two-dimensional magic angle spinning NMR investigation of naturally occurring chitins: Precise ${ }^{1} \mathrm{H}$ and ${ }^{13} \mathrm{C}$ resonance assignment of $\alpha$ - and $\beta$-chitin. Biopolymers 2004, 75, 255-263.

90. Heux, L.; Brugnerotto, J.; Desbrieres, J.; Versali, M.F.; Rinaudo, M. Solid state NMR for determination of degree of acetylation of chitin and chitosan. Biomacromolecules 2000, 1 , 746-751.

91. Poirier, M.; Charlet, G. Chitin fractionation and characterization in N, N-dimethylacetamide/ lithium chloride solvent system. Carbohydr. Polym. 2002, 50, 363-370.

92. Terbojevich, M.; Carraro, C.; Cosani, A. Solution studies of the chitin-lithium chloride-N, $N$-dimethylacetamide system. Carbohydr. Res. 1988, 180, 73-86.

93. Pillai, C.K.S.; Paul, W.; Sharma, C.P. Chitin and chitosan polymers: Chemistry, solubility and fiber formation. Prog. Polym. Sci. 2009, 34, 641-678.

94. Roberts, G.A.F. Structure of chitin and chitosan. In Chitin Chemistry; Roberts, G.A.E., Ed.; Palgrave Macmillan: London, UK, 1992; pp. 85-91.

95. Kafetzopoulos, D.; Martinou, A.; Bouriotis, V. Bioconversion of chitin to chitosan: Purification and characterization of chitin deacetylase from Mucor rouxii. Proc. Natl. Acad. Sci. USA 1993, 90, 2564-2568.

96. Aiba, S.I. Preparation of $N$-acetylchitooligosaccharides by hydrolysis of chitosan with chitinase followed by $N$-acetylation. Carbohyd. Res. 1994, 265, 323-328.

97. Ilyina, A.V.; Tatarinova, N.Y.; Varlamov, V.P. The preparation of low-molecular-weight chitosan using chitinolytic complex from Streptomyces kurssanovii. Process Biochem. 1999, 34, 875-878.

98. Tokuyasu, K.; Mitsutomi, M.; Yamaguchi, I.; Hayashi, K.; Mori, Y. Recognition of chitooligosaccharides and their $\mathrm{N}$-acetyl groups by putative subsites of chitin deacetylase from a deuteromycete, Colletotrichum lindemuthianum. Biochemistry 2000, 39, 8837-8843.

99. Kurita, K.; Sannan, T.; Iwakura, Y. Studies on chitin, 4: Evidence for formation of block and random copolymers of $N$-acetyl-D-glucosamine and D-glucosamine by hetero- and homogeneous hydrolyses. Makromol. Chem. 1977, 178, 3197-3202. 
100. No, H.K.; Meyers, S.P. Preparation and characterization of chitin and chitosan-A review. J. Aquat. Food Prod. Technol. 1995, 2, 27-52.

101. Hajji, S.; Younes, I.; Ghorbel-Bellaaj, O.; Hajji, R.; Rinaudo, M.; Nasri, M.; Jellouli, K. Structural differences between chitin and chitosan extracted from three different marine sources. Int. J. Biol. Macromol. 2014, 65, 298-306.

102. Chang, K.L.B.; Tsai, G.; Lee, J.; Fu, W.R. Heterogeneous $N$-deacetylation of chitin in alkaline solution. Carbohyd. Res. 1997, 303, 327-332.

103. Sannan, T.; Kurita, K.; Iwakura, Y. Studies on chitin, 2. Effect of deacetylation on solubility. Makromol. Chem. 1976, 177, 3589-3600.

104. Rinaudo M.; Domard, A. Solution properties of chitosan. In Chitin and Chitosan; Skjak-Bræk, G., Anthonsen, T., Stanford, P., Eds.; Kluwer Academic Publisher: Dordrecht, The Netherlands, 1989; pp. 71-86.

105. Aiba, S.I. Studies on chitosan: 3. evidence for the presence of random and block copolymer structures in partially $\mathrm{N}$-acetylated chitosans. Int. J. Biol. Macromol. 1991, 13, 40-44.

106. Berger, J.; Reist, M.; Chenite, A.; Felt-Baeyens, O.; Mayer, J.M.; Gurny, R. Erratum to Pseudo-thermosetting chitosan hydrogels for biomedical application. Int. J. Pharm. 2005, 28, 197-206.

107. Rong, H.C.; Hwa, H.D. Effect of molecular weight of chitosan with the same degree of deacetylation on the thermal, mechanical, and permeability properties of the prepared membrane. Carbohydr. Polym. 1996, 29, 353-358.

108. Li, Q.; Dunn, E.T.; Grandmaison, E.W.; Goosen, M.F.A. Applications and properties of chitosan. J. Bioact. Compat. Pol. 1992, 7, 370-397.

109. Rege, P.R.; Block, L.H. Chitosan processing: Influence of process parameters during acidic and alkaline hydrolysis and effect of the processing sequence on the resultant chitosan's properties. Carbohydr. Res. 1999, 321, 235-245.

110. Tolaimate, A.; Desbrieres, J.; Rhazi, M.; Alagui, A.; Vincendon, M.; Vottero, P. On the influence of deacetylation process on the physicochemical characteristics of chitosan from squid chitin. Polymer 2000, 41, 2463-2469.

111. Tsaih, M.L.; Chen, R.H. The effect of reaction time and temperature during heterogenous alkali deacetylation on degree of deacetylation and molecular weight of resulting chitosan. J. Appl. Polym. Sci. 2003, 88, 2917-2923.

112. Sannan, T.; Kurita, K.; Iwakura, Y. Studies on chitin. V. Kinetics of deacetylation reaction. Polym. J. 1977, 9, 649-651.

113. Weska, R.F.; Moura, J.M.; Batista, L.M.; Rizzi, J.; Pinto, L.A.A. Optimization of deacetylation in the production of chitosan from shrimp wastes: Use of response surface methodology. J. Food Eng. 2007, 80, 749-753.

114. Hwang, K.T.; Jung, S.T.; Lee, G.D.; Chinnan, M.S.; Park, Y.S.; Park, H.J. Controlling molecular weight and degree of deacetylation of chitosan by response surface methodology. J. Agr. Food Chem. 2002, 50, 1876-1882.

115. Younes, I.; Ghorbel-Bellaaj, O.; Chaabouni, M.; Rinaudo, M.; Souard, F.; Vanhaverbeke, C.; Nasri, M. Use of a fractional factorial design to study the effects of experimental factors on the chitin deacetylation. Int. J. Biol. Macromol. 2014, 70, 385-390. 
116. Le Dung, P.; Milas, M.; Rinaudo, M.; Desbrières, J. Water soluble derivatives obtained by controlled chemical modifications of chitosan. Carbohydr. Polym. 1994, 24, 209-214.

117. Tsigos, I.; Martinou, A.; Kafetzopoulos, D.; Bouriotis, V. Chitin deacetylases: New, versatile tools in biotechnology. Trends Biotechnol. 2000, 18, 305-312.

118. Araki, Y.; Ito. E. A pathway of chitosan formation in Mucor rouxii: Enzymatic deacetylation of chitin. Eur. J. Biochem. 1975, 189, 249-253.

119. Martinou, A.; Kafetzopoulos, D.; Bouriotis, V. Isolation of chitin deacetylase from Mucor rouxii by immunoaffinity chromatography. J. Chromatogr. 1993, 644, 35-41.

120. Gao, X.D.; Katsumoto, T.; Onodera, K. Purification and characterization of chitin deacetylase from Absidia coerulea. J. Biochem. 1995, 117, 257-263.

121. Alfonso, C.; Nuero, O.M.; Santamaría, F.; Reyes, F. Purification of a heat stable chitin deacetylase from Aspergillus nidulans and its role in cell wall degradation. Curr. Microbiol. 1995, 30, 49-54.

122. Tsigos, I.; Bouriotis, V. Purification and characterization of chitin deacetylase from Colletotrichum lindemuthianum. J. Biol. Chem. 1995, 270, 26286-26291.

123. Tokuyasu, K.; Kameyama, M.O.; Hiyashi, K. Purification and characterization of extracellular chitin deacetylase from Colletotrichum lindemuthianum. Biosci. Biotechnol. Biochem. 1996, 60, 1598-1603.

124. Sundara, R.G.; Aruchami, M.; Gowri, N. Natural deacetylation of chitin to chitosan in the abdominal cuticle of the physogastric queen of Macrotermes estherae. In Proceeding Second International Conference Chitin/Chitosan, Sapporo, Japan, 12-14 July 1982; Tokura S., Hirano, S., Eds.; Japanese Soc. Chitin: Tottori, Japan, 1982.

125. Martinou, A.; Kafetzopoulos, D.; Bouriotis, V. Chitin deacetylation by enzymatic means: Monitoring of deacetylation processes. Carbohydr. Res. 1995, 273, 235-242.

126. Martinou, A.; Bouriotis, V.; Stokke, B.T.; Vårum, K.M. Mode of action of chitin deacetylase from M. rouxii on partially $N$-acetylated chitosans. Carbohydr. Res. 1998, 311, 71-78.

127. Philippova, O.E.; Volkov, E.V.; Sitnikova, N.L.; Khokhlov, A.; Desbrières, J.; Rinaudo, M. Two types of hydrophobic aggregates in aqueous solutions of chitosan and its hydrophobic derivative. Biomacromolecules 2001, 2, 483-490.

128. Philippova, O.E.; Korchagina, E.V.; Volkov, E.V.; Smirnov, V.A.; Khokhlov, A.R.; Rinaudo, M. Aggregation of some water-soluble derivatives of chitin in aqueous solutions: Role of the degree of acetylation and effect of hydrogen bond breaker. Carbohydr. Polym. 2012, 87, 687-694.

129. Maghami, G.G.; Roberts, G.A.F. Evaluation of the viscometric constants for chitosan. Makromol. Chem. 1988, 189, 195-200.

130. Auzely, R.; Rinaudo, M. Controlled chemical modifications of chitosan characterization and investigation of original properties. Macromol. Biosci. 2003, 3, 562-565.

131. Rinaudo, M.; le Dung. P.; Milas, M. A new and simple method of synthesis of carboxymethyl chitosans, In Advances in Chitin and Chitosan; Brine, C.J., Sanford, P.A., Zitakis, J.P., Eds.; Elsevier: London, UK, 1992; pp. 516-525.

132. Desbrieres, J.; Martinez, C.; Rinaudo, M. Hydrophobic derivatives of chitosan: Characterization and rheological behaviour. Int. J. Biol. Macromol. 1996, 19, 21-28. 
133. Rinaudo, M.; Auzely, R.; Vallin, C.; Mullagaliev, I. Specific interactions in modified chitosan systems. Biomacromolecules 2005, 6, 2396-2407.

134. Auzely-Velty, R.; Rinaudo, M. New supramolecular assemblies of a cyclodextrin grafted chitosan through specific complexation. Macromolecules 2002, 35, 7955-7962.

135. Recillas, M.; Silva, L.L.; Peniche, C.; Goycoolea, F.M.; Rinaudo, M.; Argelles-Monal, W.M. Thermoresponsive behavior of chitosan-g- $N$-isopropylacrylamide copolymer solutions. Biomacromolecules 2009, 10, 1633-1641.

136. Rinaudo, M. New way to crosslink chitosan in aqueous solution. Eur. Polym. J. 2010, 46, 1537-1544.

137. Saito, H.; Tabeta, R.; Ogawa, K. High-resolution solid-state ${ }^{13} \mathrm{C}-\mathrm{NMR}$ study of chitosan and its salts with acids: Conformational characterization of polymorphs and helical structures as viewed from the conformation-dependent ${ }^{13} \mathrm{C}$ chemical shifts. Macromolecules 1987, 20, 2424-2430.

138. Raymond, L.; Morin, F.G.; Marchessault, R.H. Degree of deacetylation of chitosan using conductometric titration and solid-state NMR. Carbohydr. Res. 1993, 246, 331-336.

139. Varum, K.M.; Anthonsen, M.W.; Grasdalen, H.; Smisrød, O. Determination of the degree of $\mathrm{N}$-acetylation and the distribution of $\mathrm{N}$-acetyl groups in partially $\mathrm{N}$-deacetylated chitins (chitosans) by high-field n.m.r. spectroscopy. Carbohydr. Res. 1991, 211, 17-23.

140. Varum, K.M.; Anthonsen, M.W.; Grasdalen, H.; Smisrød, O. 13 C-NMR studies of the acetylation sequences in partially $\mathrm{N}$-deacetylated chitins (chitosans). Carbohydr. Res. 1991, 217, 19-27.

141. Rinaudo, M.; Milas, M.; le Dung, P. Characterization of chitosan. Influence of ionic strength and degree of acetylation on chain expansion. Int. J. Biol. Macromol. 1993, 15, 281-285.

142. Brugnerotto, J.; Desbrieres, J.; Roberts, G.; Rinaudo, M. Characterization of chitosan by steric exclusion chromatography. Polymer 2001, 42, 9921-9927.

143. Odijk, T. On the ionic-strength dependence of the intrinsic viscosity of DNA. Biopolymers 1979, 18, 3111-3113.

144. Mazeau, K.; Perez, S.; Rinaudo, M. Predicted influence of $N$-acetyl group content on the conformational extension of chitin and chitosan chains. J. Carbohydr. Chem. 2000, 19, 1269-1284.

145. Wei, Y.C.; Hudson, S.M.; Mayer, J.M.; Kaplan, D.L. The crosslinking of chitosan fibers. J. Polym. Sci. Part A Polym. Chem. 1992, 30, 2187-2193.

146. Welsh, E.R.; Price, R.R. Chitosan cross-linking with a water-soluble, blocked diisocyanate. 2. Solvates and hydrogels. Biomacromolecules 2003, 4, 1357-1361.

147. Arguelles-Monal, W.; Goycoolea, F.M.; Peniche, C.; Higuera-Ciapara, I. Rheological study of the chitosan/glutaraldehyde chemical gel system. Polym. Gels Netw. 1998, 6, 429-440.

148. Hirano, S.; Yamaguchi, R.; Fukui, N.; Iwata, M. A chitosan oxalate gel: Its conversion to an $N$-acetylchitosan gel via a chitosan gel. Carbohydr. Res. 1990, 201, 145-149.

149. Yamaguchi, R.; Hirano, S.; Arai, Y.; Ito, T. Chitosan salt gels thermally reversible gelation of chitosan. Agric. Biol. Chem. 1978, 42, 1981-1982.

150. Yokoyama, A.; Yamamoto, S.; Kawasaki, T.; Kohgo, T.; Nakasu, M. Development of calcium phosphate cement using chitosan and citric acid for bone substitute materials. Biomaterials 2002, 23, 1091-1101. 
151. Shen, X.; Tong, H.; Jiang, T.; Zhu, Z.; Wan, P.; Hu, J. Homogeneous chitosan/carbonate apatite/citric acid nanocomposites prepared through a novel in situ precipitation. Compos. Sci. Technol. 2007, 67, 2238-2245.

152. Hsieh, S.H.; Chen, W.H.; Wei, L.L. A spectroscopic analysis of the reaction mechanism of polycarboxylic acid crosslinking with chitosan and cotton fabric. Cellul. Chem. Technol. 2003, 37, 359-369.

153. Desai, K.G.H.; Park, H.J. Encapsulation of vitamine C in tripolyphosphate cross-linked chitosan microspheres by spray drying, J. Microencapsul. 2005, 22, 179-192.

154. Quemeneur, F.; Rinaudo, M.; Maret, G.; Pepin-Donat, B. Decoration of lipid vesicles by polyelectrolytes: Mechanism and structure. Soft Matter 2010, 6, 4471-4481.

155. Rinaudo, M.; Quemeneur, F.; Pepin-Donat, B. Stabilization of liposomes against stress using polyelectrolytes: Interaction mechanisms, influence of $\mathrm{pH}$, molecular weight, and polyelectrolyte structure. Int. J. Polym. Anal. Charact. 2009, 14, 667-677.

156. Bordi, F.; Sennato, S.; Truzzolillo, D. Polyelectrolyte-induced aggregation of liposomes: A new cluster phase with interesting applications. J. Phys. Condens. Matter 2009, 21, 203102:1-203102:26.

157. Haidar, Z.S.; Hamdy, R.C.; Tabrizian, M. Protein release kinetics for core-shell hybrid nanoparticles based on the layer-by-layer assembly of alginate and chitosan on liposomes. Biomaterials 2008, 29, 1207-1215.

158. Boddohi, S.; Killingsworth, C.E.; Kipper, M.J. Polyelectrolyte multilayer assembly as a function of $\mathrm{pH}$ and ionic strength using the polysaccharides chitosan and heparin. Biomacromolecules 2008, 9, 2021-2028.

159. Hillberg, A.L.; Tabrizian, M. Biorecognition through layer-by-layer polyelectrolyte assembly: In situ hybridation on living cells. Biomacromolecules 2006, 7, 2742-2750.

160. Majima, T.; Funakosi, T.; Iwasaki, N.; Yamane, S.T.; Harada, K.; Nonaka, S.; Minami, A.; Nishimura, S.I. Alginate and chitosan polyion complex hybrid fibers for scaffolds in ligament and tendon tissue engineering. J. Orthopaedic. Sci. 2005, 10, 302-307.

161. Iwasaki, N.; Yamane, S.T.; Majima, T.; Kasahara, Y.; Minami, A.; Harada, K.; Nanaka, S.; Maekawa, N.; Tamura, H.; Tokura, S.; et al. Feasibility of polysaccharide hybrid materials for scaffolds in cartilage tissue engineering: Evaluation of chondrocyte adhesion to polyion complex fibers prepared from alginate and chitosan. Biomacromolecules 2004, 5, 828-823.

162. Chung, T.W.; Yang, J.; Akaike, T.; Cho, K.Y.; Nah, J.W.; Kim, S.I.; Cho, C.S. Preparation of alginate/galactosylated chitosan scaffold for hepatocyte attachment. Biomaterials 2002, 23, 282-283.

163. Lavertu, M.; Méthot, S.; Tran-Khanh, N.; Buschmann, M.D. High efficiency gene transfer using chitosan/DNA nanoparticles with specific combinations of molecular weight and degree of deacetylation. Biomaterials 2006, 27, 4815-4824.

164. Jean, M.; Smaoui, F.; Lavertu, M.; Méthot, S.; Bouhdoud, L.; Buschmann, M.D.; Merzouki, A. Chitosan-plasmid nanoparticle formulations for IM and SC delivery of recombinant FGF-2 and PDGF-BB or generation of antibodies. Gene Ther. 2009, 16, 1097-1110.

165. Alameh, M.Z.; Jean, M.; Dejesus, D.; Buschmann, M.D.; Merzouki, A. Chitosanase-based method for RNA isolation from cells transfected with chitosan/siRNA nanocomplexes for real-time RT-PCR in gene delivery. Int. J. Nanomedecine 2010, 5, 473-481. 
166. Thibault, M.; Nimesh, S.; Lavertu, M.; Buschmann, M. Intracellular trafficking and decondensation kinetics of chitosan-pDNA polyplexes. Mol. Ther. 2010, 18, 1787-1795.

167. Strand, S.P.; Danielsen, S.; Christensen, B.E.; Varum, K.M. Influence of chitosan structure on the formation and stability of DNA-Chitosan polyelectrolyte complexes. Biomacromolecules 2005, 6, 3357-3366.

168. Farkas, V. Fungal cell walls: Their structure, biosynthesis and biotechnological aspects. Acta Biotechnol. 1990, 10, 225-238.

169. Fleet, G.H.; Phaff, H.J. Fungal glucans-structure and metabolism. Encycl. Plant Physiol. N $S$ 1981, 13B, 416-440.

170. Friedman, M.; Juneja, V.K. Review of Antimicrobial and Antioxidative Activities of Chitosans in Food. J. Food Protect. 2010, 73, 1737-1761.

171. Kardas, I.; Struszczyk, M.H.; Kucharska, M.; van den Broek, L.A.M.; van Dam, J.E.G.; Ciechańska, D. Chitin and chitosan as functional biopolymers for industrial applications. In The European Polysaccharide Network of Excellence (EPNOE). Research Initiatives and Results; Narvard. P., Ed.; Springer-Verlag: Wien, Austria, 2012; pp. 329-374.

172. Alishahi, A.; Aïder, M. Applications of chitosan in the seafood industry and aquaculture: A review. Food Bioprocess Technol. 2012, 5, 817-830.

173. Bordenave, N.; Grelier, S.; Cama, V. Water and moisture susceptibility of chitosan and paper-based materials: Structure-property relationships. J. Agric. Food Chem. 2007, 55, 9479-9488.

174. Franklin, T.J.; Snow, G.A. Biochemistry of Antimicrobial Action; 3rd ed.; Chapman and Hall: London, UK, 1981; p. 217.

175. Synowiecki, J.; Al-khatteb, N.A.A. Production, properties and some new applications of chitin and its derivatives. Crit. Rev. Food Sci. Nut. 2003, 43, 144-171.

176. Sudarshan, N.R.; Hoover, D.G.; Knorr, D. Antibacterial action of chitosan. Food Biotechnol. 1992, 6, 257-272.

177. Leuba, S.; Stossel, P. Chitosan and other polyamines: Antifungal activity and interaction with biological membranes. In Chitin in Nature and Technology; Muzzarelli, R.A.A., Jeuniaux, C., Gooday, C., Eds.; Plenum Press: New York, NY, USA, 1985; p. 217.

178. Choi, B.K.; Kim, K.Y.; Yoo, Y.J.; Oh, S.J.; Choi, J.H.; Kim. C.Y. In vitro antimicrobial activity of a chitooligosaccharide mixture against Actinobacillus actinomycetemcomitans and Streptococcus mutans. Int. J. Antimicrob. Agent 2001, 18, 553-557.

179. Eaton, P.; Fernandes, J.C.; Pereira, E.; Pintado, M.E.; Malcata. F.X. Atomic force microscopy study of the antibacterial effects of chitosans on Escherichia coli and Staphylococcus aureus. Ultramicroscopy 2008, 108, 1128-1134.

180. Chung, Y.C.; Su, Y.P.; Chen, C.C.; Jia, G.; Wang, H.L.; Wu, J.G.; Lin, J.G. Relationship between antibacterial activity of chitosan and surface characteristics of cell wall. Acta Pharm. Sin. 2004, 25, 932-936.

181. Jeon, Y.J.; Park, P.J.; Kim, S.K. Antimicrobial effect of chitooligosaccharides produced by bioreactor. Carbohydr. Polym. 2001, 44, 71-76.

182. Muzzarelli, R.; Tarsi, R.; Filippini, O.; Giovanetti, E.; Biagini, G.; Varaldo, P.E. Antimicrob. Agents Chemother. 1990, 34, 2019-2023. 
183. Rhoades, J.; Roller, S. Antimicrobial actions of degraded and native chitosan against spoilage organisms in laboratory media and foods. Appl. Environ. Microbiol. 2000, 66, 80-86.

184. Helander, I.M.; Nurmiaho-Lassila, E.L.; Ahvenainen, R.; Rhoades, J.; Roller. S. Chitosan disrupts the barrier properties of the outer membrane of Gram-negative bacteria. Int. J. Food Microbiol. 2001, 71, 235-244.

185. No, H.K.; Young Park, N.; ho Lee, S.; Meyers. S.P. Antibacterial activity of chitosans and chitosan oligomers with different molecular weights. Int. J. Food Microbiol. 2002, 74, 65-72.

186. Younes, I.; Sellimi, S.; Rinaudo, M.; Jellouli, K.; Nasri, M. Influence of acetylation degree and molecular weight of homogeneous chitosans on antibacterial and antifungal activities. Int. J. Food Microbiol. 2014, 185, 57-63.

187. Zheng, L.Y.; Zhu. J.F. Study on antimicrobial activity of chitosan with different molecular weights. Carbohydr. Polym. 2003, 54, 527-530.

188. Benhabiles, M.S.; Salah, R.; Lounici, H.; Drouiche, N.; Goosen, M.F.A.; Mameri, N. Antibacterial activity of chitin, chitosan and its oligomers prepared from shrimp shell waste. Food Hydrocolloid. 2012, 29, 48-56.

189. Bell, A.A.; Hubbard, J.C.; Liu, L.; Davis, R.M.; Subbarao, K.V. Effects of chitin and chitosan on the incidence and severity of Fusarium yellows of celery. Plant Dis. 1998, 82, 322-328.

190. Ben-Shalom, N.; Ardi, R.; Pinto, R.; Aki, C.; Fallik. E. Controlling gray mould caused by Botrytis cinerea in cucumber plants by means of chitosan. Crop. Prot. 2003, 22, 285-290.

191. Wojdyła. A.T. Chitosan (Biochikol 020 PC) in the control of some ornamental foliage diseases. Commun. Agric. Appl. Biol. Sci. 2004, 69, 705-715.

192. Atia, M.M.M.; Buchenauer, H.; Aly, A.Z.; Abou-Zaid, M.I. Antifungal activity of chitosan against Phytophthora infestans and activation of defence mechanisms in tomato to late blight. Biol. Agric. Hortic. 2005, 23, 175-197.

193. Photchanachai, S.; Singkaew, J.; Thamthong, J. Effects of chitosan seed treatment on Colletotrichum sp. and seedling growth of chili cv. "jinda". In ISHS Acta Horticulturae 712, Proceedings of the IV International Conference on Managing Quality in Chains-The Integrated View on Fruits and Vegetables Quality, Bangkok, Thailand, 30 June 2006; Purvis, A.C., McGlasson, W.B., Kanlayanarat, S., Eds.; International Society for Horticultural Science: Leuven, Belgium, 2006; pp. 585-590.

194. Bai, R.K.; Huang, M.Y.; Jiang, Y.Y. Selective permeabilities of chitosan-acetic acid complex membrane and chitosan-polymer complex membranes for oxygen and carbon dioxide. Polym. Bull. 1988, 20, 83-88.

195. El-Ghaouth, A.; Arul, J.; Asselin, A.; Benhamou, N. Antifungal activity of chitosan on two postharvest pathogens of strawberry fruits. Phytopathology 1992, 82, 398-402.

196. Ames, B.N.; Gold, L.S.; Willet, W.C. Causes and prevention of cancer. Proc. Nat. Acad. Sci. USA 1995, 92, 5258-5265.

197. Pincernail, J. Free radicals and antioxidants in human disease. In Analysis of Free Radicals in Biological Systems; Favier, A.E., Cadet, J., Kalyanaraman, B., Fontecave, M., Pierre, J.L., Eds.; Birkhauser: Basel, Switzerland, 1995; pp. 83-98.

198. Stadtman, E.R. Protein oxidation and aging. Science 1992, 257, 1220-1224.

199. Witztum, J.L. The oxidation hypothesis of atherosclerosis. Lancet 1994, 344, 793-795. 
200. Ames, B.N.; Shigenaga, M.K.; Hagan, T.M. Oxidants, antioxidants and the degenerative diseases of aging. Proc. Natl. Acad. Sci. USA 1993, 90, 7915-7922.

201. Halliwell, B.; Murcia, M.A.; Chirico, S.; Aruoma, O.I. Free radicals and antioxidants in food and in vivo: What they do and how they work. Crit. Rev. Food Sci. Nutr. 1995, 35, 7-20.

202. Halliwell, B. Free radicals, antioxidants and human disease: Curiosity, cause or consequence. Lancet 1994, 344, 721-724.

203. Chiang, M.T.; Yao, H.T.; Chen, H.C. Effect of dietary chitosans with different viscosity on plasma lipids and lipid peroxidation in rats fed on a diet enriched with cholesterol Biosci. Biotech. Bioch. 2000, 5, 965-971.

204. Park, P.J.; Je, J.Y.; Kim S.K. Free radical scavenging activity of chitooligosaccharides by electron spin resonance spectrometry J. Agric. Food Chem. 2003, 51, 4624-4627.

205. Sun, T.; Xie, W.; Xu, P. Antioxidant activity of graft chitosan derivatives. Macromol. Biosci. 2003, 3, 320-323.

206. Yin, X.Q.; Lin, Q.; Zhang, Q.; Yang. L.C. $\mathrm{O}_{2}{ }^{-}$scavenging activity of chitosan and its metal complexes. Chin. J. Appl. Chem. 2002, 19, 325-328.

207. Kim, K.W.; Thomas, R.L. Antioxidative activity of chitosans with varying molecular weights. Food Chem. 2007, 101, 308-313.

208. Je, J.Y.; Park, P.J.; Kim, S.K. Free radical scavenging properties of hetero-chitooligosaccharides using an ESR spectroscopy. Food Chem. Toxicol. 2004, 42, 381-387.

209. Qi, L.; Xu, Z. In vivo antitumor activity of chitosan nanoparticles. Bioorg. Med. Chem. Lett. 2006, 16, 4243-4245.

210. Dass, C.R.; Choong, P.F. The use of chitosan formulations in cancer therapy. J. Microencapsul. 2008, 25, 275-279.

211. Chen, W.R.; Adams, R.L.; Carubelli, R.; Nordquist, R.E. Laser-photosensitizer assisted immunotherapy: A novel modality for cancer treatment. Cancer Lett. 1997, 115, 25-30.

212. Nishimura, K.; Nishimura, S.; Nishi, N.; Saiki, I.; Tokura, S.; Azuma, I. Immunological activity of chitin and its derivatives. Vaccine 1984, 2, 93-99.

213. Tokoro, A.; Tatewaki, N.; Suzuki, K.; Mikami, T.; Suzuki, S.; Suzuki, M. Growth inhibitory effect of hexa- $N$-acetylchitohexaose and chitohexaos and Meth-A solid tumor. Chem. Pharm. Bull. (Tokyo) 1998, 36, 784-790.

214. Murata, J.; Saiki, I.; Nishimura, S.; Nishi, N.; Tokura, S.; Azuma, I. Inhibitory effect of chitin heparinoids on the lung metastasis of B16-BL6 melanoma. Jpn. J. Cancer Res. 1989, 80, 866-872.

215. Hasegawa, M.; Yagi, K.; Iwakawa, S.; Hirai, M. Chitosan induces apoptosis via caspase-3 activation in bladder tumor cells. Jpn. J. Cancer Res. 2001, 92, 459-466.

216. Qi, L.; Xu, Z.; Chen, M. In vitro and in vivo suppression of hepatocellular carcinoma growth by chitosan nanoparticles. Eur. J. Cancer 2007, 43, 184-193.

217. Guminska, M.; Ignacak, J.; Wojcik, E. In vitro inhibitory effect of chitosan and its degradation products on energy metabolism in Ehrlich ascites tumour cells (EAT). Polish J. Pharmacol. 1996, 48, 495-501.

218. Lin, S.Y.; Chan, H.Y.; Shen, F.H.; Chen, M.H.; Wang, Y.J.; Yu, C.K. Chitosan prevents the development of AOM-induced aberrant crypt foci in mice and suppressed the proliferation of AGS cells by inhibiting DNA synthesis. J. Cell Biochem. 2007, 100, 1573-1580. 
219. Jeon, Y.J.; Kim. S.K. Antitumor activity of chitosan oligosaccharides produced in an ultra filtration membrane reactor system. J. Microbiol. Biotechn. 2002, 12, 503-507.

220. Suzuki, K.; Mikami, T.; Okawa, Y.; Tokoro, A.; Suzuki, S.; Suzuki, M. Antitumor effect of hexa- $N$-acetylchitohexaose and chitohexaose. Carbohydr. Res. 1986, 151, 403-408.

221. Huang, M.; Khor, E.; Lim, L.Y. Uptake and cytotoxicity of chitosan molecules and nanoparticles: Effects of molecular weight and degree of deacetylation. Pharm. Res. 2004, 21, 344-353.

222. Younes, I.; Frachet, V.; Rinaudo, M.; Jellouli, K.; Nasri, M. Sfax University, Sfax, Tunisia. Cytotoxicity of homogeneous chitosans with different acetylation degrees and molecular weight on bladder carcinoma cells. 2015, Unpublished work.

223. Ravi Kumar, M.N.V.; Muzzarelli, R.A.A.; Muzzarelli, C.; Sashiwa, H.; Domb, A.J. Chitosan Chemistry and Pharmaceutical Perspectives. React. Funct. Polym. 2000, 46, 1-27.

224. Patil, R.S.; Ghormade, V.; Deshpande, M.V. Chitinolytic enzymes: An exploration. Enzym. Microb. Technol. 2000, 26, 473-483.

225. Venter, J.P.; Kotze, A.F; Auzely-Velty, R.; Rinaudo, M. Synthesis and evaluation of the mucoadhesivity of a CD-chitosan derivative. Int. J. Pharm. 2006, 313, 36-42.

226. Khor, E. Chitin: A biomaterial in waiting. Curr. Opin. Solid State Mater. Sci. 2002, 6, 313-317.

227. Maeda, Y.; Jayakumar, R.; Nagahama, H.; Furuike, T.; Tamura, H. Synthesis, characterization and bioactivity studies of novel b-chitin scaffolds for tissue-engineering applications, Int. J. Biol. Macromol. 2008, 42, 463-467.

228. Nagahama, H.; Nwe, N.; Jayakumar, R.; Koiwa, S.; Furuike, T.; Tamura, H. Novel biodegradable chitin membranes for tissue engineering applications. Carbohydr. Polym. 2008, 73, 295-302.

229. Yang, T.L. Chitin-based materials in tissue engineering: Applications in soft tissue and epithelial organ. Int. J. Mol. Sci. 2011, 12, 1936-1963.

230. Mi, F.L.; Lin, Y.M.; Wu, Y.B.; Shyu, S.S.; Tsai, Y.H. Chitin/PLGA blend microspheres as a biodegradable drug-delivery system: Phase-separation, degradation and release behavior. Biomaterials 2002, 23, 3257-3267.

231. Illum, L.; Davis, S. Chitosan as a delivery system for the transmucosal administration of drugs. In Polysaccharides. Structural Diversity and Functional Versatility, 2nd ed.; Dumitriu, S., Ed.; Marcel Dekker Publisher: New York, NY, USA, 2005; pp. 643-660.

232. Kumirska, J.; Weinhold, M.X.; Thöming, J.; Stepnowski, P. Biomedical Activity of Chitin/Chitosan Based Materials-Influence of Physicochemical Properties Apart from Molecular Weight and Degree of $N$-Acetylation. Polymers 2011, 3, 1875-1901.

233. Jayakumar, R.; Menon, D.; Manzoor, K.; Nair, S.V.; Tamura, H. Biomedical applications of chitin and chitosan based nanomaterials-A short review. Carbohydr. Polym. 2011, 82, 227-232.

234. Aranaz, I.; Mengíbar, M.; Harris, R.; Paños, I.; Miralles, B.; Acosta, N.; Galed, G.; Heras, A. Functional Characterization of Chitin and Chitosan. Curr. Chem. Biol. 2009, 3, 203-230.

235. Dutta, P.K.; Dutta, J.; Tripathi, V.S. Chitin and chitosan: Chemistry, properties and applications. J. Sci. Ind. Res. India 2004, 63, 20-31.

236. Park, B.K.; Kim, M-M. Applications of chitin and its derivatives in biological medicine. Int. J. Mol. Sci. 2010, 11, 5152-5164. 
237. Cheba, B.A. Chitin and Chitosan: Marine Biopolymers with Unique Properties and Versatile Applications. Glob. J. Biotechnol. Biochem. 2011, 6, 149-153.

238. De Alvarenga, E.S. Characterization and properties of chitosan. In Biotechnology of Biopolymers; Elnashar, M., Ed.; In Tech: Rijeka, Croatia, 2011; pp. 91-108.

239. Kim, S.K. Chitin and Chitosan Derivatives: Advances in Drug Discovery and Developments; Kim, S.K., Ed.; CRC Press: Boca Raton, FL, USA, 2013.

240. Sarmento, B.; Das Neves, J. Chitosan-Based Systems for Biopharmaceuticals: Delivery, Targeting and Polymer Therapeutics. Wiley \& Sons: Hoboken, NJ, USA, 2012.

241. Park, B.K.; Kim, M.M. Applications of Chitin and Its Derivatives in Biological Medicine. Int. J. Mol. Sci. 2010, 11, 5152-5164.

242. Dash, M.; Chiellini, F.; Ottenbrite, R.M.; Chiellini, E. Chitosan-A versatile semi-synthetic polymer in biomedical applications. Prog. Polym. Sci. 2011, 36, 981-1014.

243. Kanke, M.; Katayama, H.; Tsuzuki, S.; Kuramoto, H. Application of chitin and chitosan to pharmaceutical preparations. Chem. Pharm. Bull. 1989, 37, 523-525.

244. Kato, Y.; Onishi, H.; Machida, Y. Application of chitin and chitosan derivatives in the pharmaceutical field. Curr. Pharm. Biotechnol. 2003, 4, 303-309.

245. Felse, P.A.; Panda, T. Studies on applications of chitin and its derivatives. Bioprocess Eng. 1999, 20, 505-512.

246. Yusof, N.L.; Wee, A.; Lim, L.Y.; Khor, E. Flexible chitin films as potential wound-dressing materials: Wound model studies. J. Biomed. Mater. Res. Part A 2003, 66A, 224-232.

247. Liu, J.; Zhu, L. Method for preparing chitin composite artificial skin that can be used as woundplast. Faming Zhuanli Shenqing CN 101411897 A 20090422, 2009.

248. Wongpanit, P.; Sanchavanakit, N.; Pavasant, P.; Supaphol, P.; Tokura, S.; Rujiravanit, R. Preparation and characterization of microwave-treated carboxymethylchitin and carboxymethylchitosan films for potential use in wound care application. Macromol. Biosci. 2005, 5, 1001-1012.

249. Muzzarelli, R.A.A.; Morganti, G.; Palombo, P.; Biagini, G.; Mattioli Belmonte, M.; Giantomassi, F.; Orlandi, F.; Muzzarelli, C. Chitin nanofibrils/chitosan glycolate composites as wound medicaments. Carbohydr. Polym. 2007, 70, 274-284.

250. Bernkop-Schnurch, A. Mucoadhesive polymers. In Polymeric Biomaterials; Dumitriu, S., Ed., Marcel Dekker: New York, NY, USA, 2002; pp. 147-165.

251. Ito, M. In vitro properties of a chitosan-bonded hydroxyapatite bone-filling paste. Biomaterials 1991, 12, 41-45.

252. Swetha, M.; Sahithi, K.; Moorthi, A.; Srinivasan, N.; Ramasamy, K.; Selvamurugan, N. Biocomposites containing natural polymers and hydroxyapatite for bone tissue engineering. Int. J. Biol. Macromol. 2010, 47, 1-4.

253. Khor, E.; Lim, L.Y. Implantable applications of chitin and chitosan. Biomaterials 2003, 24, 2339-2349.

254. Vankatesan, J.; Kim, S.K. Chitosan composites for bone tissue engineering - an overview. Mar. Drugs 2010, 8, 2252-2266.

255. El Zein, A.R.; Dabbarh, F.; Chaput, C. Injectable self-setting calcium phosphate cement. In Chitosan in Pharmacy and Chemistry; Muzzarelli, R.A.A., Muzzarelli, C., Eds.; ATEC: Grottammare, Italy, 2002; pp. 365-370. 
256. Yi, H.; Wu, L.Q.; Bentley, W.E.; Ghadssi, R.; Rubloff, G.W.; Culver, J.N.; Payne, G.F. Biofabrication with chitosan. Biomacromolecules 2005, 6, 2881-2894.

257. Saravanan, S.; Nethala, S.; Pattnaik, S.; Tripathi, A.; Moorthi, A.; Selvamurugan, N. Preparation, characterization and antimicrobial activity of a bio-composite scaffold containing chitosan/ nano-hydroxyapatite/nano-silver for bone tissue engineering. Int. J. Biol. Macromol. 2011, 49, 188-193.

258. Venkatesan, J.; Kim, S.K. Chitosan Composites for Bone Tissue Engineering-An Overview. Mar. Drugs 2010, 8, 2252-2266.

259. Teng, S.; Lee, E.; Yoon, B.; Shin, D.; Kim, H.; Oh, J. Chitosan/nanohydroxyapatite composite membranes via dynamic filtration for guided bone regeneration. J. Biomed. Mater. Res. Part A 2009, 88, 569-580.

260. Bin, J.; Feng, Y.; Zhi-kun, L. Basic fibroblast growth factor combined with nano-hydroxyapatite/chitosan composites for repair of radial bone defects in rabbits. Chin. J. Tissue Eng. Res. 2012, 16, 6343-6348.

261. Costa-Pinto, A.R.; Reis, R.L.; Neves, N.M. Scaffolds based bone tissue engineering: The role of chitosan. Tissue Eng. Part B Rev. 2011, 17, 331-347.

262. Krajewska, B. Application of chitin- and chitosan-based materials for enzyme immobilizations: A review. Enzym. Microb. Technol. 2004, 35, 126-139.

263. Freier, T.; Montenegro, R.; Koh, S.; Shoichet, M.S. Chitin tubes for tissue engineering in the nervous system. Biomaterials 2005, 26, 4624-4632.

264. Yang, T.L. Chitin-based Materials in Tissue Engineering: Applications in Soft Tissue and Epithelial Organ. Int. J. Mol. Sci. 2011, 12, 1936-1963.

265. Kuo, S.M.; Niu, G.C.; Chang, S.J.; Kuo, C.H.; Bair, M.S. A one - step method for fabricating chitosan microspheres. J. Appl. Polym. Sci. 2004, 94, 2150-2157.

266. Honarkar, H.; Barikani, M. Applications of biopolymers I: Chitosan. Monatsh. Chem. 2009, 140, $1403-1420$.

267. Özbas-Turan, S.; Aral, C.; Kabasakal, L.; Keyer-Uysal, M.; Akbuga, J. Co-encapsulation of two plasmids in chitosan microspheres as a non-viral gene delivery vehicle. J. Pharm. Pharmaceut. Sci. 2003, 6, 27-32.

268. Ohkawa, K.; Minato, K.I.; Kumagai, G.; Hayashi, S.; Yamamoto, H. Chitosan nanofiber. Biomacromolecules 2006, 7, 3291-3294.

269. Kucharska, M.; Niekraszewicz, A.; Lebioda, J.; Malczewska-Brzoza, K.; Wesołowska, E. Bioactive Composite Materials In Progress on Chemistry and Application of Chitin and Its Derivatives; Jaworska, M.M., Ed.; Polish Chitin Society: Lodz, Poland, 2007; Volume 12, pp. 131-138.

270. Dhanikula, A.B.; Panchagnula, R. Development and characterization of biodegradable chitosan films for local delivery of paclitaxel. AAPS J. 2004, 6, 88-89.

271. Kucharska, M.; Struszczyk, M.H.; Cichecka, M.; Brzoza, K. Preliminary studies on the usable properties of innovative wound dressings. In Progress on Chemistry and Application of Chitin and Its Derivatives; Jaworska, M.M., Ed.; Polish chitin Society: Lotz, Poland, 2011; Volume 16, pp. 131-137. 
272. Pereira, A.O.; Cartucho, D.J.; Duarte, A.S.; Gil, M.H.; Cabrita, A.; Patricio, J.A.; Barros, M.M. Immobilisation of cardosin A in chitosan sponges as a novel implant for drug delivery. Curr. Drug Discov. Technol. 2005, 2, 231-238.

273. Illum, L. Chitosan and its use as a pharmaceutical excipient. Pharm. Res. 1998, 15, 1326-1331.

274. Dai, T.; Tanaka, M.; Huang, Y.Y.; Hamblin, M.R. Chitosan preparations for wounds and burns: Antimicrobial and wound-healing effects. Expert Rev. Anti. Infect. Ther. 2011, 9, 857-879.

275. Jayakumar, R.; Prabaharan, M.; Sudheesh Kumar, P.T.; Nair, S.V.; Tamura, H. Biomaterials based on chitin and chitosan in wound dressing applications. Biotechnol. Adv. 2011, 29, 322-337.

276. Loke, W.K.; Lau, S.K; Yong, L.L.; Khor, E.; Sum, C.K. Wound dressing with sustained anti-microbial capability. J. Biomed. Mater. Res. 2000, 53, 8-17.

277. Kumari, R.; Dutta, P.K. Physicochemical and biological activity study of genipin-crosslinked chitosan scaffolds prepared by using supercritical carbon dioxide for tissue engineering applications. Int. J. Biol. Macromol. 2010, 46, 261-266.

278. Luna-barcenas, G.; Prokhorov, E.; Elizalde-pena, E.; Nuno-licona, A.; Sanchez, I.C. Chitosan-Based Hydrogels for Tissue Engineering Applications, Biotechnology in Agriculture, Industry and Medicine Series; Nova Science Publisher: New York, NY, USA, 2011.

279. Croisier, F.; Jérôme, C. Chitosan-based biomaterials for tissue engineering. Eur. Polym. J. 2013, 49, 780-792.

280. Riva, R.; Ragelle, H.; des Rieux, A.; Duhem, N.; Jérôme, C.; Préat, V. Chitosan and chitosan derivatives in drug delivery and tissue engineering. In Chitosan for Biomaterials II; Jayakumar, R., Prabaharan, M., Muzzarelli, R.A.A., Eds.; Springer: Berlin-Heidelberg, Germany, 2011, pp. 19-44.

281. Suh, J.K.F.; Matthew, H.W.T. Application of chitosan-based polysaccharide biomaterials in cartilage tissue engineering: A review. Biomaterials 2000, 21, 2589-2598.

282. Shi, C.; Zhu, Y.; Ran, X.; Wang, M.; Su, Y.; Cheng, T. Therapeutic potential of chitosan and its derivatives in regenerative medicine. J. Surg. Res. 2006, 133, 185-192.

283. Farzaneh, N.H.; Soheila, S.K.; Faramarz, A.T.; Zahra, A. Novel Topical Biocompatible Tissue Adhesive Based on Chitosan-modified Urethane Pre- S polymer. Iran Polym. J. 2011, 20, 671-680.

284. Kotzé, A.F.; Hamman, J.H.; Snyman, D.; Jonker, C.; Stander, M. Mucoadhesive and absorption enhancing properties of $N$-trimethyl chitosan chloride. In Chitosan in Pharmacy and Chemistry; Muzzarelli, R.A.A., Muzzarelli, C., Eds.; ATEC: Grottammare, Italy, 2002; pp. 31-40.

285. Rickett, T.A.; Amoozgar, Z.; Tuchek, C.A.; Park, J.; Yeo, Y.; Shi, R. Rapidly photo-cross-linkable chitosan hydrogel for peripheral neurosurgeries. Biomacromolecules 2011, 12, 57-65.

286. Hamman, J.H.; Kotzé, A.F. Paracellular absorption enhancement across intestinal epithelia by $N$-trimethyl chitosan chloride. In Chitosan in Pharmacy and Chemistry; Muzzarelli, R.A.A., Muzzarelli, C., Eds.; ATEC: Grottammare, Italy, 2002; pp. 41-50.

287. Miwa, A.; Ishibe, A.; Nakano, M.; Yamahira, T.; Itai, S.; Jinno, S.; Kawahara, H. Development of novel chitosan derivatives as micellar carriers of taxol. Pharm. Res. 1998, 15, 1844-1850.

288. Liu, W.; Sun, S.J.; Zhang, X.; de Yao, K. Self-aggregation behaviour of alkylated chitosan and its effect on the release of a hydrophobic drug. J. Biomater. Sci. Polym. Edn. 2003, 14, 851-859.

289. Liu, W.; Zang, X.; Sun, S.J.; Sun, G.J.; Yao, K.D.; Liang, D.C.; Guo, G.; Zhang, J.Y. N-alkylated chitosan as a potential nonviral vector for gene transfection. Bioconjug. Chem. 2003, 14, 782-789. 
290. Ouchi, T.; Murata, J.I.; Ohya, Y. Gene delivery by quaternary chitosan with antennary galactose residues. In Polysaccharide Applications: Cosmetics and Pharmaceuticals; El-Nokaly, M.A., Soini, H.A., Eds.; American Chemical Society: Washington, DC, USA, 1999; pp. 15-23.

291. Mi, F.L.; Shyu, S.S.; Chen, C.T.; Schoung, J.Y. Porous chitosan microspheres suitable for controlling the antigen release of Newcastle disease vaccine: Preparation of antigen-adsorbed microsphere and in vitro release. Biomaterials 1999, 20, 1603-1612.

292. Park, I.K.; Jiang, H.L.; Yun, C.H.; Choi, Y.J.; Kim, S.J.; Akaike, T.; Kim, S.I.; Cho, C.S. Release of Newcastle disease virus vaccine from chitosan microspheres in vitro and in vivo. Asian-Aust. J. Anim. Sci. 2004, 17, 543-547.

293. Foda, N.H.; El-Iaithy, M.; Tadros, I. Implantable biodegradable sponges: Effect of interpolymer complex formation of chitosan with gelatin on the release behavior of tramadol hydrochloride. Drug Dev. Ind. Pharm. 2007, 33, 7-17.

294. Dhanaraj, S.A.; Selvadurai, M.; Santhi, K.; Hui, A.L.S.; Wen, C.J.; Teng, H.C. Targeted drug delivery system:-formulation and evaluation of chitosan nanospheres containing doxorubicin hydrochloride. Int. J. Drug Deliv. 2014, 6, 186-193.

295. Makhlof, A.; Tozuka, Y.; Takeuchi, H. Design and evaluation of novel pH-sensitive chitosan nanoparticles for oral insulin delivery. Eur. J. Pharm. Sci. 2011, 42, 445-451.

296. Cheng, S.Y.; Yuen, M.C.; Lam, P.L.; Gambari, R.; Wong, R.S.; Cheng, G.Y.; Lai, P.B.; Tong, S.W.; Chan, K.W.; Lau, F.Y.; et al. Synthesis, characterization and preliminary analysis of in vivo biological activity of chitosan/celecoxib microcapsules. Bioorg. Med. Chem. Lett. 2010, 20, 4147-4151.

(C) 2015 by the authors; licensee MDPI, Basel, Switzerland. This article is an open access article distributed under the terms and conditions of the Creative Commons Attribution license (http://creativecommons.org/licenses/by/4.0/). 